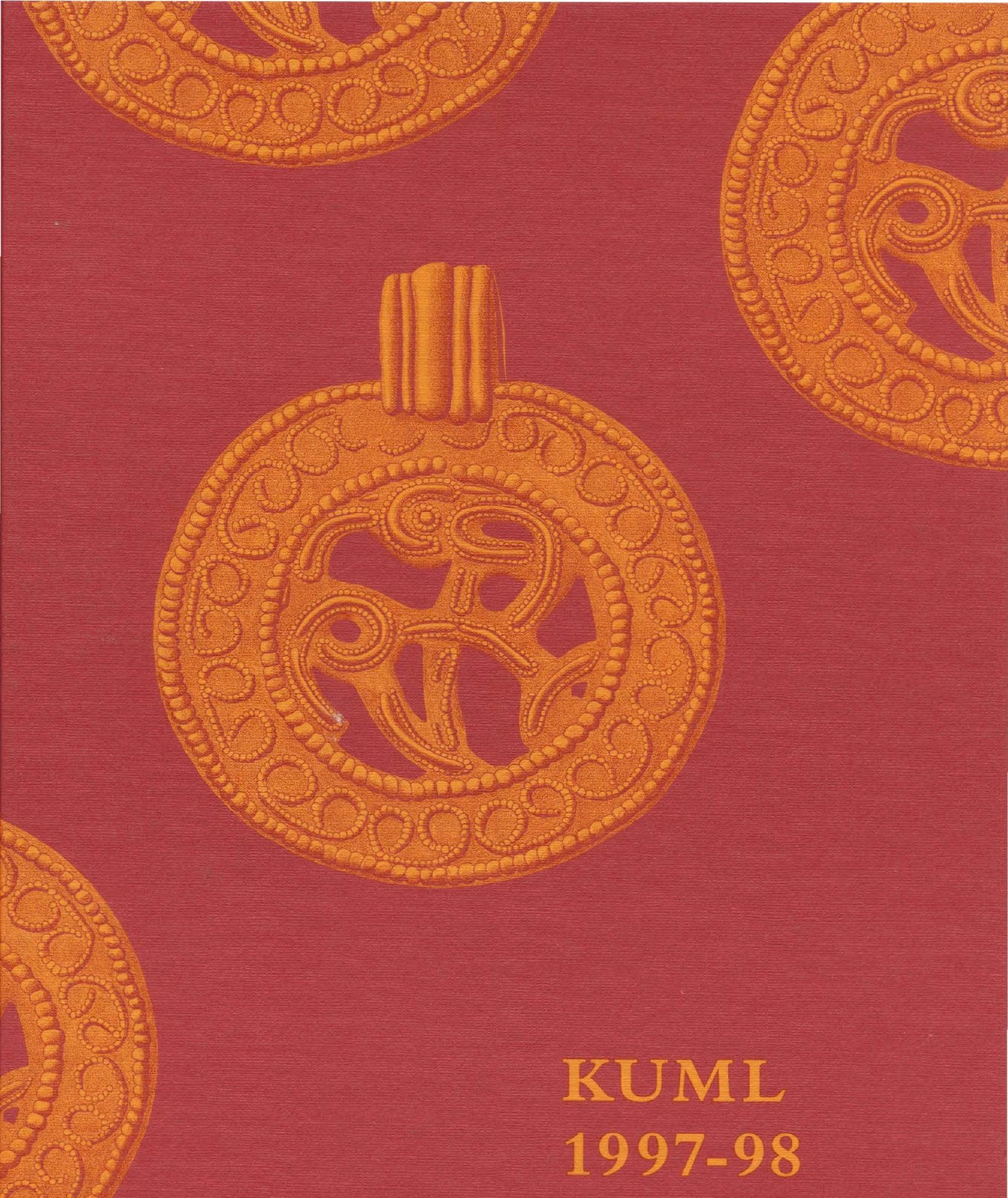


KUML 1999 


\section{KUML 1999}

\section{Årbog for Jysk Arkæologisk Selskab}

With summaries in English

I kommission hos Aarhus Universitetsforlag 
Redaktion: Jesper Laursen

Omslag: Jorgen Mührmann-Lund

Korrektur: Anne Lise Hansen, Hanne Plaetner og Jytte Rabild

Tilrettelagning: Narayana Press

Tryk: Narayana Press

Skrift: Bembo 12/13

Papir: $115 \mathrm{~g}$ Arctic Silk

Copyright (C) 1999 Jysk Arkcoologisk Selskab

ISBN 87-88415-01-5

ISSN 0454-6245 


\section{Indhold/Contents}

Jan Skamby Madsen: Hans Jørgen Madsen - Worsaae-medaillen 13. maj $1999 \quad \ldots \ldots \ldots \ldots$

Hans Jørgen Madsen - the Worsaae Medal 13th of May 1999 . . . . . . . . . . . . 9

Lutz Klassen: Prestigeøkser af sjældne alpine bjergarter

En glemt og overset fundgruppe fra ældre stenalders slutning i Danmark $\ldots \ldots \ldots . .11$

Prestige axes of rare alpine rock - A forgotten and overlooked find group from

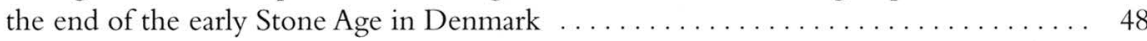

Kirsten Prangsgaard, Svend Th. Andersen, Henrik Breuning-Madsen,

Mads Holst, Claus Malmros og David Robinson: Gravhøje ved Lejrskov

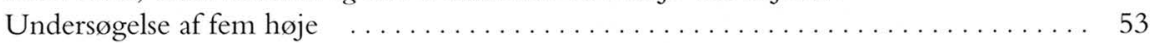

The investigation of five burial mounds at Lejrskov $\ldots \ldots \ldots \ldots \ldots \ldots \ldots \ldots \ldots$

Karen Margrethe Hornstrup: Brandgrave fra yngre bronzealder

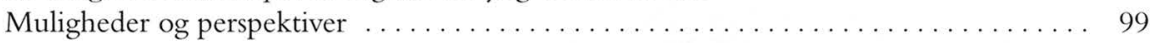

Cremation graves from the late Bronze Age - possibilities and perspectives $\ldots \ldots \ldots 142$

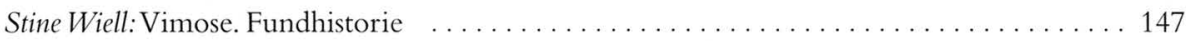

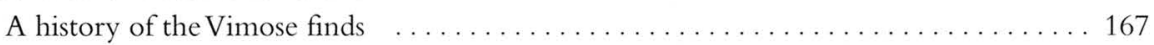

Claus von Carnap-Bornheim: Vimose. "Nye" fund . . . . . . . . . . . . . . . . . . . . 169

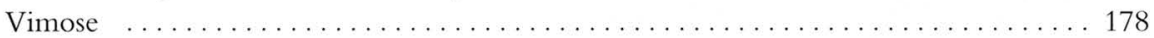

Folmer Christiansen: Jelling. Bebyggelse fra jernalder og vikingetid $\ldots \ldots \ldots \ldots \ldots 181$

Jelling. Settlements from the Iron Age and the Viking Age $\ldots \ldots \ldots \ldots \ldots \ldots 220$

Mads Ravn: Nybro. En trævej fra Kong Godfreds tid $\ldots \ldots \ldots \ldots \ldots \ldots \ldots \ldots \ldots 27$

Nybro. A wooden track from the age of King Godfred ................. 255

Bjarne Lonborg: Vikingetidens kvindedragter ... . . . . . . . . . . . . . . . . . . . . . 259

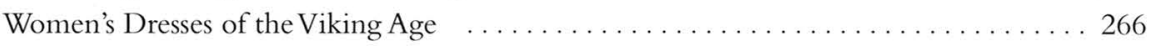

Hans Krongaard Kristensen: Hospitalsbygningen ved Øm Kloster

Arkæologisk undersøgelse af en stor senmiddelalderlig bygning

og en nyfunden kanal . . . . . . . . . . . . . . . . . . . . . . . . . . . 269

The hospital of the $Ø \mathrm{~m}$ Monastery. The archaeological investigation of

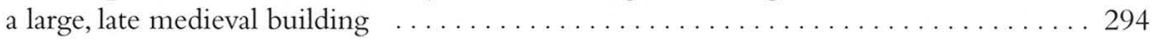

Anmeldelser ..................................................... 297

Jysk Arkæologisk Selskab 1998 . . . . . . . . . . . . . . . . . . . . . . . . . 335

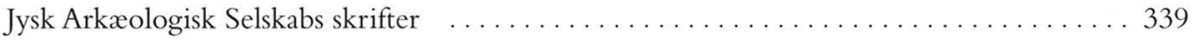




\title{
Hospitalsbygningen ved Øm Kloster
}

\section{Arkæologisk undersøgelse af en stor senmiddelalderlig bygning og en nyfunden kanal}

\author{
Af Hans KrongaARd Kristensen
}

Umiddelbart før afslutningen på Olaf Olsens store udgravningskampagne på Øm Kloster i 1970'erne anlagde man et felt øst for østfløjen for at efterspore den kirke, munkene havde brugt frem til 1257. Den hastigt gennemførte undersøgelse afslørede ikke spor efter den gamle kirke, men til gengæld var der rester af en stor senmiddelalderlig bygning. Også ved en senere lejlighed påvistes bygningsrester i området, omend den nøjere udformning og sammenhæng mellem resterne var vanskelig at tolke. En sammentegning af resultaterne antydede, at der kunne være tale om to bygninger, samt et meget kompliceret kanalforløb (fig. 1). ${ }^{1}$

Med henblik på en afklaring af bygningsresternes sammenhæng og de mystiske kanalers placering besluttede Afdelingen for Middelalderarkæologi ved Aarhus Universitet at afholde uddannelsesgravning i Øm Kloster $i$ årene 1994-96. Udgravningen skulle samtidig fungere som en markering af 100 års jubilæet for den forste udgravning i Øm i 1896.

Et krav i forbindelse med tilladelsen til at grave i det fredede anlæg var, at eventuelle ruinrester blev tildækket igen, hvilket skete efter hvert års udgravningskampagne. Det udgravede bygningskompleks er altså ikke synligt i dag og har heller ikke under undersøgelsen været afdækket i sin helhed. Registreringen er således foretaget i tre etaper. ${ }^{2}$

Først efter den sidste undersøgelse kunne bygningskomplekset forstås helt, men den langvarige udgravningsproces gav anledning til midlertidige tolkningsforslag operende med to bygninger på hver sin side af en kanal, hvor vi i dag regner med én bygning, hvorunder vandet har passeret (fig. 2). 


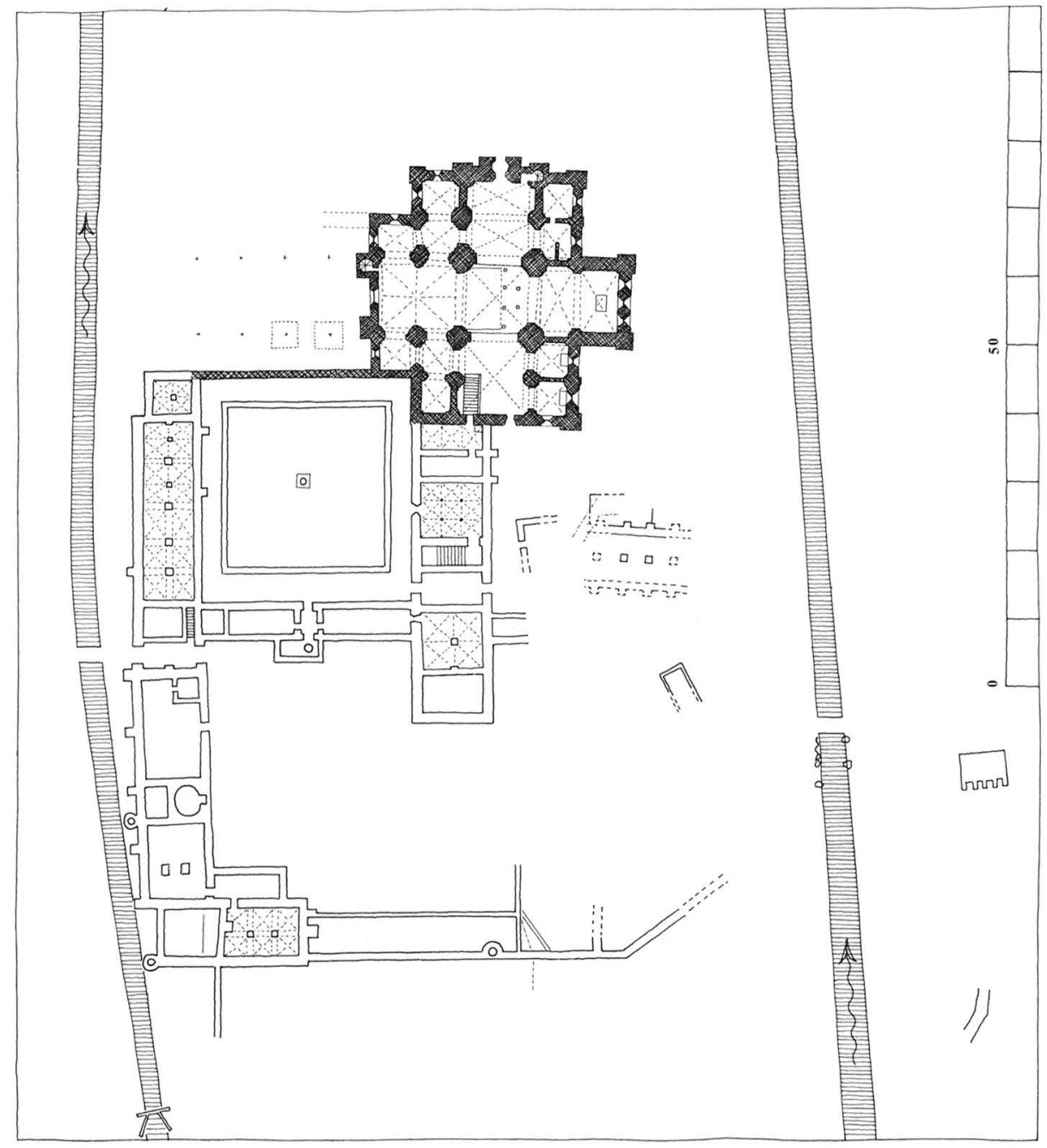

Fig. 1. Plan af de udgravede dele af klosterkomplekset frem til 1989. På planen er bygningerne rekonstrueret med formodede murværkstykkelser og åbninger. I virkeligheden har man mange steder kun påvist fundamenter. Kirken er fremhævet med skravering. Øst for østfløjen er indtegnet nogle usammenhængende bygningsrester. Det er her, udgravningerne 1994-96 har påvist en stor bygning, hvorunder der løb en kanal. Sammentegning af Kjeld de Fine Licht i Danmarks Kirker, Århus Amt.

Survey of the monastery showing the parts excavated prior to 1989 . The wall thickness and openings are reconstructed, as in many places nothing but the foundations were left. The dark signature marks the church. Some disconnected building remains are seen east of the east wing. This was where the 1994-96-excavation uncovered a large building overlying a canal. Drawing by Kjeld de Fine Licht, from Danmarks Kirker, Århus Amt. 


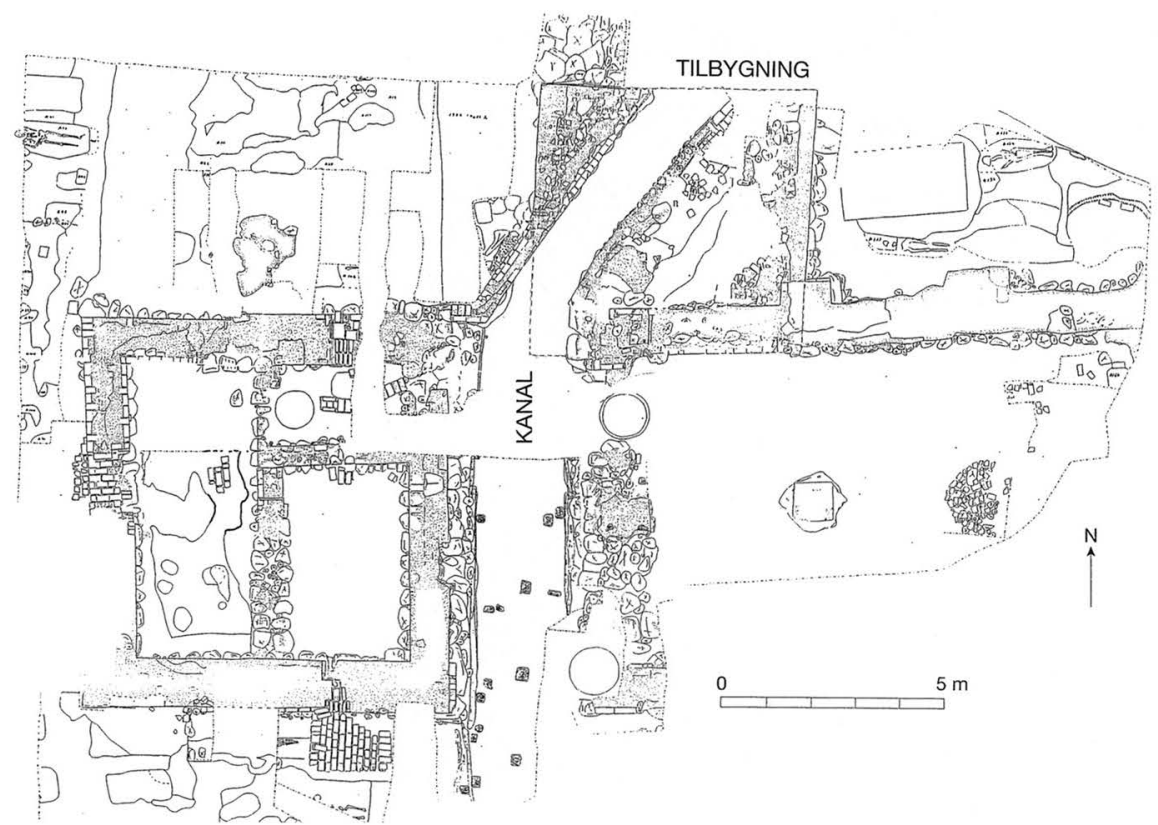

Fig. 2. Samlet plan af hospitalsbygningen og kanalen afdækket ved undersøgelsen 1994-96. Opmåling: studerende ved Afd. for Middelalderarkæologi. Sammentegning af Ib Radoor og HKK.

Plan of the hospital and the canal found during the 1994-95-excavation. Measured by students from the Department of Medieval Archaeology. Drawn by Ib Radoor and the author.

\section{Bygningen}

Den undersøgte bygning havde en udvendig bredde på 10,8 m. Længden kendes ikke. Ved undersøgelsen afdækkedes $24 \mathrm{~m}$ af nordmuren. Østgavlen findes et sted under landsbygaden. Et snit øst for vejen viste, at bygningen ikke fortsatte på denne side.

Bygningen bestod af to adskilte dele på hver sin side af kanalen. I begge tilfælde var der tale om kælderrum, og det forekommer mest sandsynligt, at de to dele har været bygget sammen i den overliggende etage. Som det fremgår nedenfor, var kanalen allerede gammel, da huset blev opført.

\section{Fundering}

Huset var bygget på et solidt kampestensfundament med sten i vekslende størrelse - de største med dimensioner op til $80 \mathrm{~cm}$. Et par enkelte steder indgik der granitkvadre i det øverste fundamentskifte. Indvendigt sluttede fundamenterne stort set i samme niveau (kote 24,00-24,18), mens kampestenene på ydersiden har fulgt det skrånende terræn opad bort fra 


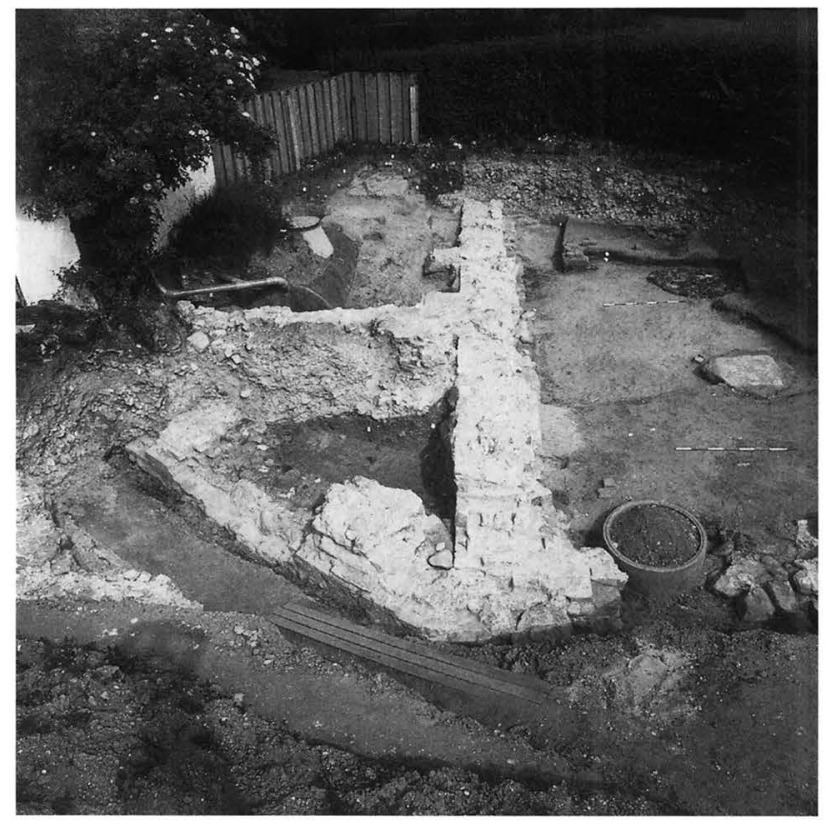

Fig. 3. Udgravningsområdet 1995 set fra vest. I midten ses hospitalsbygningens nordmur med stræbepiller. Til højre er der fundamenter til hvælvpiller og til venstre tilbygningen mod nord. Foto: HKK 1995.

The area excavated in 1995 photographed from the West. The northern hospital wall with buttresses is seen in the middle. To the right are the foundations of for the pillars carrying the vaults. The northern extension is seen to the left.

kanalen. Her dannede de øverste sten lagt i mørtel en synlig syld. I nordvesthjørnet toppede sylden i kote 24,89 .

\section{Murvark}

Ydermurene var opført som kassemure af munkesten. Forskellige steder var der korte strækninger med rulskifte lige over fundamentet for at udligne en lidt ujævn afretning. Ellers var murværket opført i munkeskifte med de uregelmæssigheder, som forskellige åbninger naturligt medfører. Ydermurenes tykkelse androg mod syd og vest $100 \mathrm{~cm}$, nordmuren i øst $110 \mathrm{~cm}$. Ogningen her var foretaget med en halvstensfals $3,2 \mathrm{~m}$ fra nordvesthjørnet.

Den østlige del af huset var mod nord forsynet med stræbepiller med en bredde på $120 \mathrm{~cm}$ og et fremspring på ca. $50 \mathrm{~cm}$. Stræbepillerne var opført i forbandt med nordmuren (fig. 3). På den bedst bevarede var der fire skifter oppe en $1 / 4$ stens tilbagerykning på nordsiden, så der dannedes en art sokkel. I forbindelse med udgravningen påvistes to stræbepiller samt begyndelsen på en tredje. Der var ingen piller på hjørnerne, hvorimod de var anbragt ud for fritstående piller $\mathrm{i}$ bygningens indre og har dannet en regelmæssig fagdeling. Det kan derfor afgøres, at bygningen har strakt sig mindst 5,5 m (et fag) længere mod øst, dvs. at huset har været mindst $29,5 \mathrm{~m}$ langt.

Ud for kanalen var der spor, som viste, at der i forlængelse af langmu- 
Fig. 4. Det vestligste pillefundament i den østre kælder. Aftryk af munkestenene anes $\mathrm{i}$ det bevarede mørtellag. Foto: HKK 1995.

The foundation for the westernmost pillar in the eastern cellar. The bricks left faint impressions in the mortar.

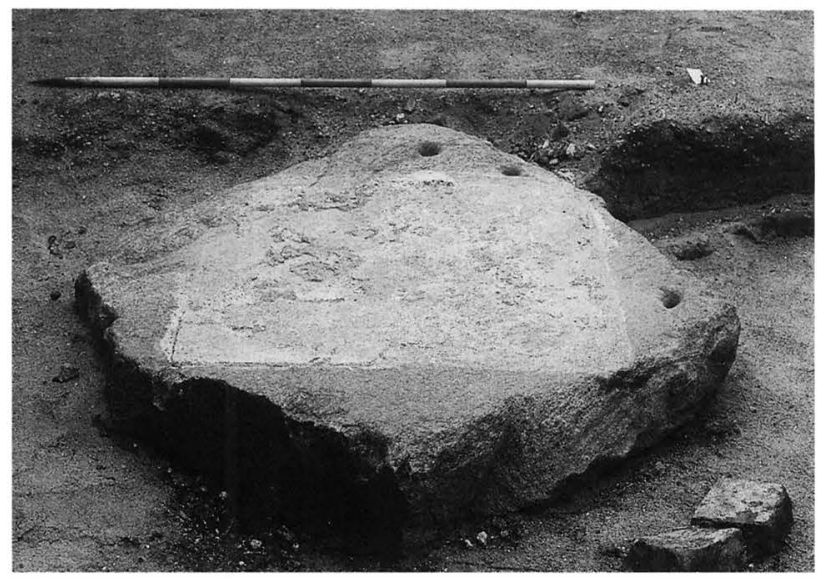

rene havde været lisenagtige fremspring mod kanalen. I den vestlige bygningsdel var fremspringet $1 / 2$ sten i en bredde af $120 \mathrm{~cm}$. På den østlige del var fremspringet formentlig $1 / 1$ sten, men på grund af en senere ombygning mindre tydeligt. Her var tilsyneladende også et fremspring på $1 / 1$ sten ud for midteraksen. Eftersom der ikke var nogen pendant på kanalens anden side, må dette fremspring betragtes som en art stræbepille bygget af hensyn til overhvælvningen. De andre fremspring ved langmurene i nord og syd må være vanger fra bueslag hen over kanalen. Herved blev disse ydermure sammenhængende i etagen over kælderstokværket.

\section{Piller, skillevogge og gulve}

Den østligste bygningsdel havde piller i midteraksen. To fundamenter blev afdækket. Mod øst var der rester af en cirkelformet fundering bestående af mindre kampesten samt halve munkesten og mindre teglbrokker. Dette var klart bunden af fundamentet, men det er lidt usikkert, hvad der havde været oven på.

Fundamentet for den vestre pille bestod af en stor flad sten (ca. $120 \times$ $130 \mathrm{~cm}$ ) (fig. 4). Stenen havde adskillige kilehuller fra kløvningsforsøg, hvor af nogle var lykkedes, andre ikke. Herpå havde man opmuret en kvadratisk pille $-90 \mathrm{~cm}$ i kvadrat, dvs. 3 sten bred. Pillen var væk, men der var tydelige aftryk i mørtelen af munkestenene. Det forekommer sandsynligt, at den østre pille kunne være funderet på samme måde.

Spor i kælderens nordvesthjørne med en diagonalstillet munkesten og afrundede mørtelpartier til hver side tyder på, at kælderen var overhvælvet med ribbehvælv, hvor ribberne startede helt nede i hjørnet.Vi må således forestille os, at kælderen skønt overhvælvet har været forholdsvis lavloftet. 


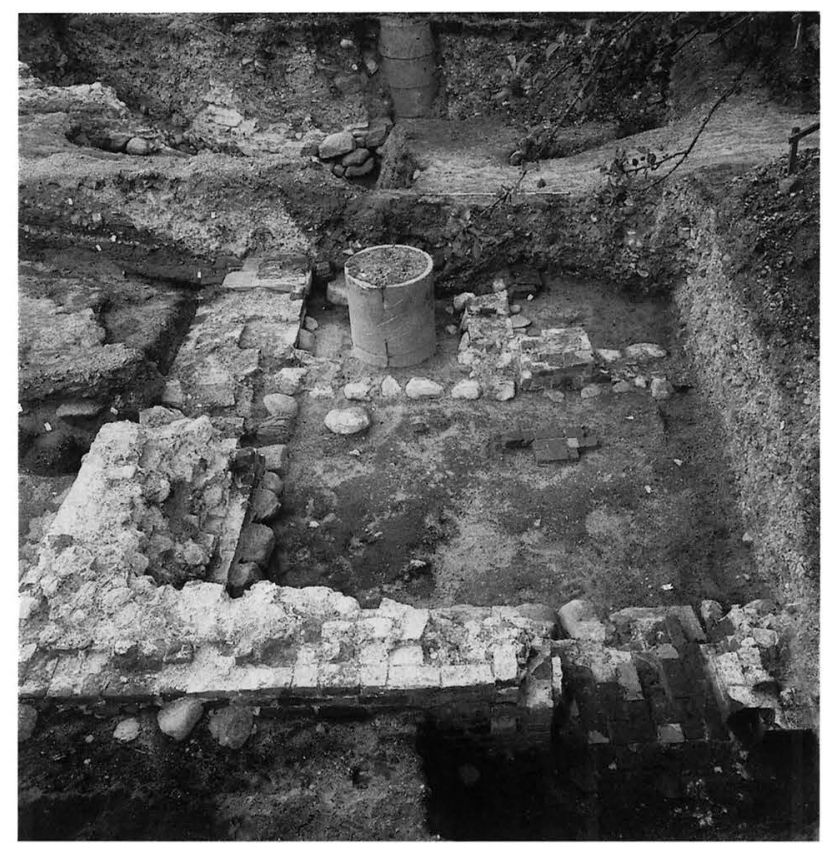

Fig. 5. Hospitalsbygningens nordvest-hjørne set fra vest. Til højre i vestgavlen ses kælderdøren mod vest. Skillevæggens fundamenter anes omkring den fritgravede brønd fra dette århundredes forste halvdel. Foto: HKK 1994.

The NW-corner of the hospital seen from the West. The western door to the cellar is seen to the right. The foundation of the partition wall is barely visible around the modern well. Photo: the author, 1994.

Den vestlige kælder var ved hjælp af skillevægge opdelt i tre rum. Så vidt man kunne se, var fundamenter og murværk i skillevæggene ikke opført i forbandt med ydermurene og kun delvis indbyrdes i forbandt. På den anden side var der dog heller intet, der tydede på, at skillevæggene ikke var bygget samtidig med husets opforelse.

Tilsyneladende var der i første omgang opført en vinkelformet skillevæg, $1 \frac{1}{2}$ sten tyk $(46 \mathrm{~cm})$, som adskilte et lille rum $(2,90 \times 1,85 \mathrm{~m}) \mathrm{i}$ nordøsthjørnet. Hertil føjedes en nord-sydgående skillevæg således, at der dannedes et stort rum i vest, der så i øst begrænsedes af en skillevæg opfort i to omgange. Alle skillevægge havde partier, hvor kun fundamenterne var bevaret, og det er derfor uklart, om der var indvendige døre mellem de tre rum.

Gulvet havde bestået af almindelige munkesten lagt på fladen - formentlig med et betydeligt indslag af brudte sten. Rummet i nordøst var forsynet med et afløb under gulvet. Bund og dække var munkesten lagt på fladen - siderne dannedes af kantstillede sten. Afløbsrendens start var desværre ødelagt af en moderne brønd (fig. 6). Renden var ført gennem ydermuren i øst, så den udmundede i kanalen. Her bestod den ene side af en genanvendt granitkvader, hvor den ene flade i øvrigt var hugget i smig. Inde i nordøstrummet fandtes en stor sten (bredde $60 \mathrm{~cm}$ ), som havde en plan, glat overside. Stenens placering var næppe tilfældig, men funktionen er uklar. Den har kun hævet sig ubetydeligt over gulvniveau. 
Fig. 6. Nærbillede af afløbet $i$ den vestre kælders nordøstrum. Bagved ses den omtalte flade sten. Afløbets start var desværre ødelagt af den moderne brønd. Foto: HKK 1994.

Close-up of the drain in the north-eastern room of the cellar. The first part of the drain was destroyed by the modern well. Photo: the author, 1994.

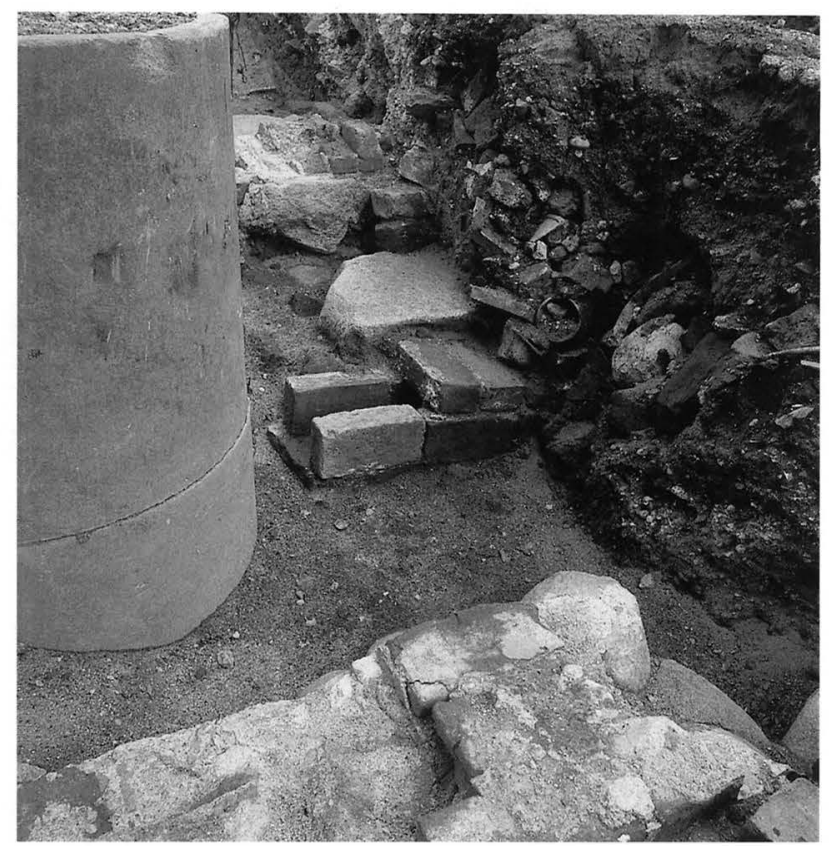

\section{Døräbninger}

Der er ikke påvist nogen døråbninger ind til det overhvælvede kælderrum i øst. På baggrund af overvejelser over terrænforhold og tilbygningen på nordsiden forekommer det rimeligt at forvente en dør ind til kælderen på sydsiden (hvor der endnu ikke har været mulighed for undersøgelser).

Det vestlige kælderafsnit havde derimod tre åbninger. Mod vest var der midt på gavlvæggen rester af en ganske velbevaret døråbning. På ydersiden var den forsynet med halvstensfals. Indvendigt var anslagsfalsen $1 \frac{1}{2}$ sten dyb, $1 / 2$ sten bred i syd og $3 / 4$ sten i nord, således at dørfløjen har været højrehængt. Dørtrinnet lå en halv sten højere end gulvet og bestod af munkesten på fladen lagt i mørtel. Ind mod kælderrummet var trinnet udformet som et rulskifte.

På gavlens yderside nord for døren var der en række overhugne bindere fra en $1 / 2$ stens fortanding, som må hidrøre fra den nordre vange ved en trappeskakt foran døren (fig. 7). Man kunne svagt ane et par trappeformede afgravninger i undergrundssandet foran døren; men ellers var både vanger og trin fra denne kældertrappe helt forsvundet. Kun to rækker halve sten foran dørtrinnet var levnet.

En anden dør var anbragt i sydmuren. Her var dog kun den vestre vange bevaret. Opbygningen var ganske lig den i vestgavlen, også her må dørfløjen have været højrehængt. Uden for døren var der udlagt et parti 


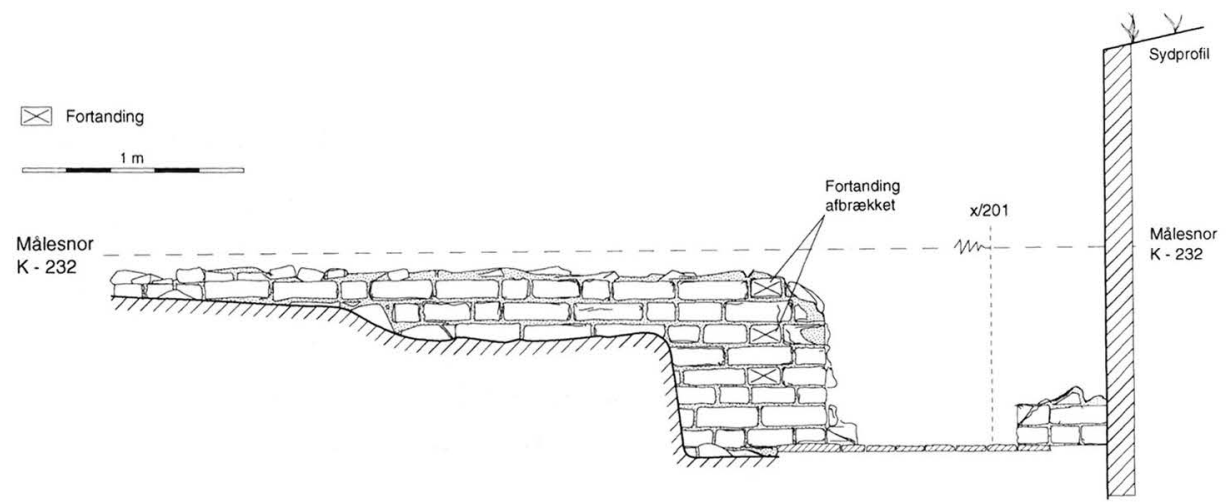

Fig. 7. Opstalt af vestdøren og det omgivne murværk set fra vest. Opmåling: Jørn B. Lund. Streg: Sven Kaae.

Elevation of the west door and the surrounding masonry, seen from the West. Measured by Jørn B. Lund. Drawn by Sven Kaae.

af munkesten (herunder også halve og trekvarte sten samt enkelte uglaserede fliser), der dannede en rektangulær flade ca. $135 \times 180 \mathrm{~cm}$ (fig. 8).

Hvordan man var kommet videre fra dette repos, kunne ikke afklares med sikkerhed. Højst sandsynligt havde der været en opgang mod vest langs husets sydmur. Her kunne man over en strækning på 2,8 $\mathrm{m}$ se et tykt trækulslag i et klart afgrænset felt $\mathrm{i}$ en bredde på 1,2 m ud fra muren. Trækullet fandtes i en ca. $10 \mathrm{~cm}$ dyb grube, der skrånede opad mod vest overlejrende enkelte hovedstore sten. Hvordan dette fænomen egentlig skal tolkes er ret uklart - måske har der været et arrangement med trætrapper både til kælderen og stueetagen. Trækullet kunne i så fald stamme fra de brændte trapper.

På nordsiden har der været en smal åbning $(70 \mathrm{~cm})$, som formentlig havde fals på ydersiden, men næppe indvendigt. Den indre halvdel af åbningen havde en bund med to rækker munkesten i rulskifte ca. $34 \mathrm{~cm}$ over gulvhøjde. I den yderste del af åbningen indgik der bl.a. genanvendte granitkvadre med sokkelprofil. Der var også flere munkesten lagt på fladen, hvoraf to ragede ca. $1 / 3$ uden for murflugten mod nord. Rulskiftet bar tydeligvis præg af slid, men hvilket formål denne specifikt udformede åbning med dens noget atypiske bundniveau har haft, vides ikke.

\section{Overetagen}

Det, at bygningen i øst var forsynet med stræbepiller, viser, at det ikke kun var kælderetagen, der var planlagt med hvælv. Også det overliggende stokværk skulle hvælves.Ved udgravningen af kanalen fandtes tre fragmenter af granitsøjler $20-22 \mathrm{~cm}$ i diameter. Om der har stået sådanne 
Fig. 8. Den sydlige del af den vestre kælder set fra øst. I sydmuren anes de nederste skifter af den falsede vestvange til syddøren og udenfor mod syd et parti brolagt med teglsten. Bagved dette ses langs husets sydmur et bredt trækulslag. Foto: HKK 1994.

The southern part of the western cellar seen from the East. The bottom courses of the rabbeted door bed are seen in the southern wall. Outside, to the South, there is a tile-paved area, behind which a wide layer of charcoal runs along the southern wall. Photo: the author, 1994.

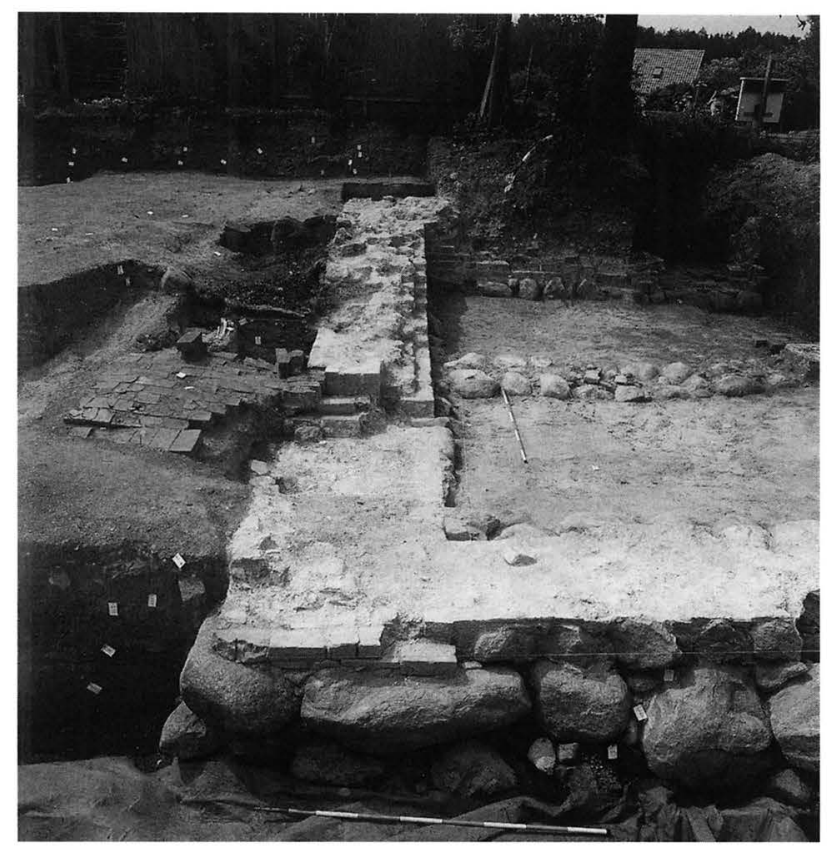

slanke søjler i bygningen er uvist (også andre rum i klostret kan have haft søjlebårne hvælv), men ikke usandsynligt. I hvert fald må vi gå ud fra, at bygningens østende har huset en toskibet sal. Stræbepillerne i dette senmiddelalderlige byggeri tyder også på, at der er tænkt på store vinduer $\mathrm{i}$ hvert fag. Det er fristende at sammenligne bygningen med Helligåndshuset i København, altså Helligåndsklostrets vestlænge, hvor der er en lys, toskibet sal med højtliggende hvælv båret af slanke granitsøjler.

Bygningens vestre del har ikke stræbepiller, så her har udformningen givet været anderledes. Murværket er solidt nok til, at man kunne forvente to stokværk af normalhøjde over kælderen. Dette gælder også for østenden, men her må vi regne med, at den overhvælvede etage har haft betydelig større rumhøjde, end en eventuel overetage. Bygningens placering på tværs af kanalen skyldes utvivlsomt, at der skulle være toiletter oven over - midt i huset.

\section{Anvendelse}

En oplagt anvendelsesmulighed for huset ville være som hospitalsbygning. Det overhvælvede rum i øst burde i så fald være sygestuen, hvortil der i umiddelbar nærhed skulle være toiletter eller neccessarier, som de kaldtes i klostrene. Hvad der kan have været i vestenden er ikke til at afgøre. 


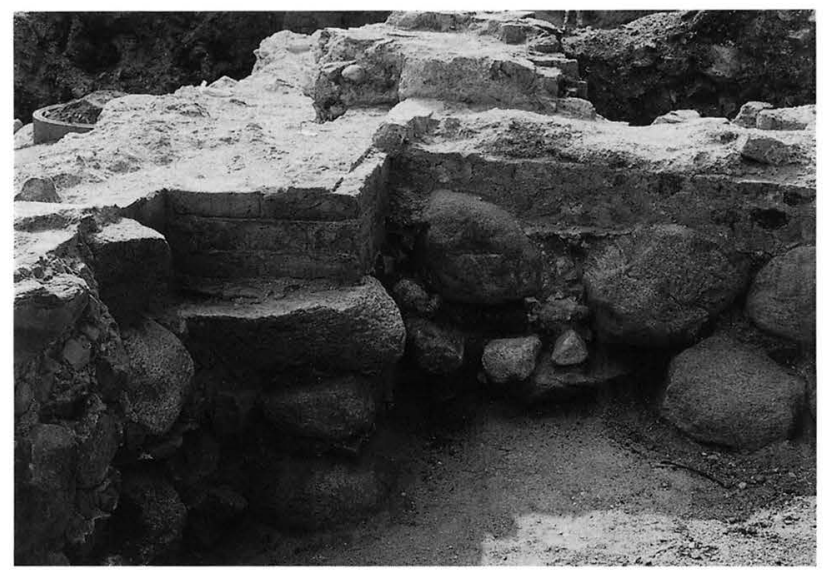

Fig. 9. Den vestligste stræbepille på hospitalsbygningen og den nordre tilbygning set fra øst. Det ses tydeligt, at tilbygningen er en senere tilføjelse, hvis fundering ligger højere end hospitalsbygningen fra 1495. Måske er tilbygningen først opført efter reformationen. Foto: HKK 1995.

The western buttress of the hospital and the northern extension, seen from the East. The extension is clearly a later addition, as its foundation lies higher than that of the hospital from 1495. Perhaps the extension was not built until after the reformation. Photo: the author, 1994.

Det store hus lå som nævnt øst for hovedanlæggets østfløj. Det betyder, at dets placering ikke på samme måde som i det centrale bygningskompleks udspringer af gamle traditioner og stærke normer. For klosterfløjene omkring fratergården herskede der specielt for cistercienserordenen en ganske stor grad af uniformitet. Det påstås, at en cisterciensermunk på rejse altid ville kunne finde rundt af sig selv i et hvert af ordenens klostre. Der var dog også visse sædvaner forbundet med placeringen af huse i yderområdet. Bl.a. var det ganske almindeligt, at klostrets infirmeri (det interne sygehus) lå øst for østfløjen. Altså på det sted, hvor det her behandlede hus i Øm er fundet. I de helt store klostre kan infirmeriet danne et helt klosteragtigt kompleks med et tilhørende kapel og en lukket gård. $\mathrm{Nu}$ har antallet af munke i Øm på ingen måde tålt sammenligning med de store europæiske klostre.Ved middelalderens slutning havde Øm næppe mere end 30 munke, hvilket betyder, at hele konventet har kunnet bo i sygestuen på én gang. Vi må derfor forestille os, at hvis bygningen har været beregnet på syge mennesker, har man tænkt på en større personkreds, end klostret selv kunne mønstre. Det forekommer derfor ret sandsynligt, at cistercienserklostret i Øm i senmiddelalderen under indtryk af den popularitet, andre klosterordner med speciale i hospitalsdrift nød i samtiden, også har valgt at drive et hospital åbent for det omgivne samfund. Man har tidligere undersøgt den store kirkegård for lægfolk ved Øm Kloster og på baggrund af fund af mange sygdomsmærkede knogler sluttet, at disse var et direkte vidnesbyrd om dette hospital. ${ }^{3}$ Det er dog vist usikkert, om frekvensen af sygdomsmærkede knogler er større i Øm end ved andre middelalderlige kirkegårde. ${ }^{4}$

Blandt de sygdomsmærkede knogler findes der også et par med spor 
efter lægeligt indgreb, bl.a. en knoglemarvsbetændelse kureret med et brændejern. Der er også fundet enkelte lægeredskaber; men da munkene ikke måtte udgyde blod, lå den egentlige kirurgi uden for deres arbejdsfelt. Derimod arbejdede de ihærdigt med plantemedicin, hvilket tydeligt er påvist i $\varnothing \mathrm{m}$ med de mange reliktplanter (forvildede planter fra klostertiden) som er påvist her. ${ }^{5}$ Mange af de kendte urtemediciner havde vanddrivende eller tarmtømmende virkning, hvorfor det var helt nødvendigt, at der var toiletfaciliteter i forbindelse med sygestuen.

\section{Tilbygningen}

På hospitalbygningens nordside var der opført en omtrent kvadratisk tilbygning $(5,1 \times 6,4 \mathrm{~m})$, hvorigennem kanalen var fort (fig. 2,3 \& 9). Den bevarede del, som stort set udelukkende må have ligget under terrænhøjde, dannede et ret kompakt murværk delt i to halvdele af kanalens diagonale forløb. Den vestlige trekant var helt kompakt, mens den østlige kun var muret/støbt i ydersiderne, mens den indre del bestod af brokkeog mørtelfyld. En meget stor del af konstruktionens tegl var genanvendte sten. Herunder var der en betydelig andel af en speciel type ribbesten, eller fragmenter heraf. Mod vest var bygningens yderside over en syld opført i et uregelmæssigt munkeskifte. Fugerne var udglattede og dækkede delvis stenene.

Nordvesthjørnet var funderet usædvanligt dybt med kraftige kampesten, hvoraf de dybestliggende var placeret ganske langt nord for murflugten. Fundamenterne var placeret $\mathrm{i}$ en form for grube, men af praktiske grunde var det ikke muligt at klarlægge årsagen hertil. Muligvis kan det hænge sammen med en ændring af kanalens forløb, idet der var dannet et skarpt knæk mod nordøst ved overgangen mellem hospitalet og tilbygningen. Måske har kanalen tidligere haft et mere retliniet forløb, således at den kraftige fundamentopbygning er anlagt i den oprindelige kanaltracé.

Kanalen var ført gennem bygningen $i$ en muret vandrende med en bredde på 1,2 m (fig. 10). Dybden kendes ikke, da indstrømmende vand i den brokkefyldte rende forhindrede en dybtgående undersøgelse. Den nederste del af siderne var opbygget af kampesten sat i mørtel med en flad side vendende udad. Herover var der tre til fire skifter munkesten i uregelmæssige skifter. Derefter fulgte et vederlag til et tøndehvælv. Af selve hvælvet var praktisk talt intet bevaret; men vederlaget var bredt nok til, at tøndehvælvet i det mindste forneden kunne have haft en tykkelse på $1 \frac{1}{2}$ sten. Da tilbygningen var anbragt, så vestflugten lå ud for midten af kanalforløbet under hospitalsbygningen, var vandrenden forlænget i sydvest, således at vandet var overdækket hele vejen. Her var rendens vestside i den øverste teglstensmurede del ca. $50 \mathrm{~cm}$ tyk.

Hvordan bygningen har set ud over terrænhøjde er lidt uvist. Om den 


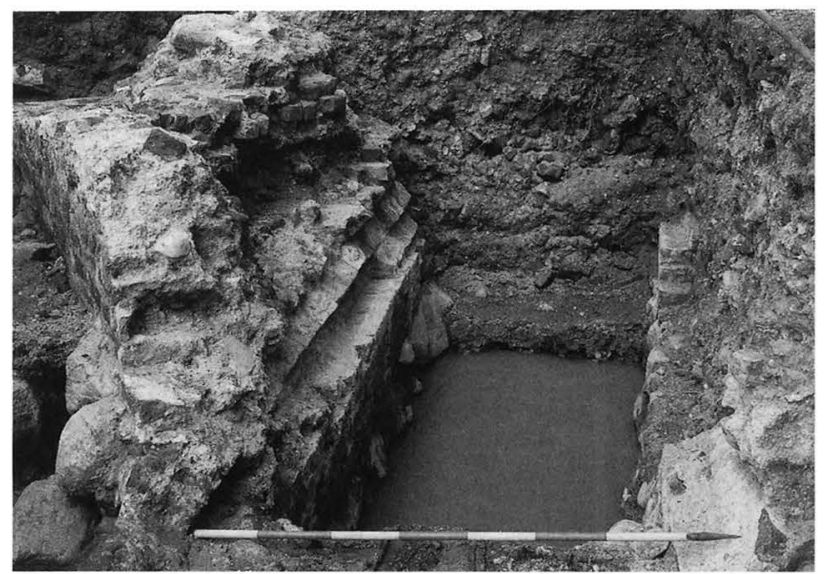

Fig. 10. Parti af den lukkede vandrende set fra syd. Rendens lodrette side er afsluttet med et skråt vederlag for hvælvet. Herover ses til venstre i billedet den nordre tilbygnings vestside. Foto: HKK 1994.

Part of the closed drain seen from the South. The sides of the drain finish in a corbel supporting the vaulting. The western side of the extension is seen in the middle of the photo. Photo: the author, 1994.

sydlige del af vestmuren har hvilet direkte på vandrendens tøndehvælv er nok usikkert - måske har en aflastningsbue i form af en kvadrant op mod hospitalets nordmur hen over kanalen fordelt murens tryk.

Formålet med tilbygningen fremgår ikke direkte af bygningsresterne. På den anden side har placeringen på tværs af kanalen medført så stort et ekstraarbejde, at man må tro, at det netop er sket for at udnytte kanalen. Sandsynligvis har man på et sent tidspunkt ønsket at flytte necessariet bort fra selve hospitalsbygningen og derfor lavet en tilbygning.

\section{Kanalen}

Undersøgelsen viste, at kanalen har haft to forskellige forløb, og at anledningen til ændringen helt klart hænger sammen med opførelsen af det store hus. I forbindelse med forskydningen blev det ældste forløb temmelig forstyrret, hvorfor beskrivelsen starter med det betydeligt bedre bevarede yngste anlæg.

Kanalens bund var antagelig nedgravet til kote 22,6; men på grund af hastigt indstrømmende vand under hele udgravningen, var det svært helt at fastlægge overgangen mellem grusunderbunden og vandaflejret sand og grus i kanalen (fig. 11). Det omtalte, aflejrede lag var meget fundrigt, men uden gennemgående lagdelinger, og sandsynligvis er der jævnligt sket forskydninger i kanalbunden.

For at hindre udvaskning fra bredderne var siderne - i hvert fald ud for bygningens fundamenter - kantet af et bolværk (fig. 12-15). Dette bestod af bøgestammer, som kløvet igennem var anbragt med den flade side ud mod vandet. Det nederste lag stammer var velbevaret, mens det øvre lag var mere nedbrudt og kun delvis bevaret. Stammerne var ikke stødt sammen ende mod ende, men var anbragt med en lille overlapning. For 


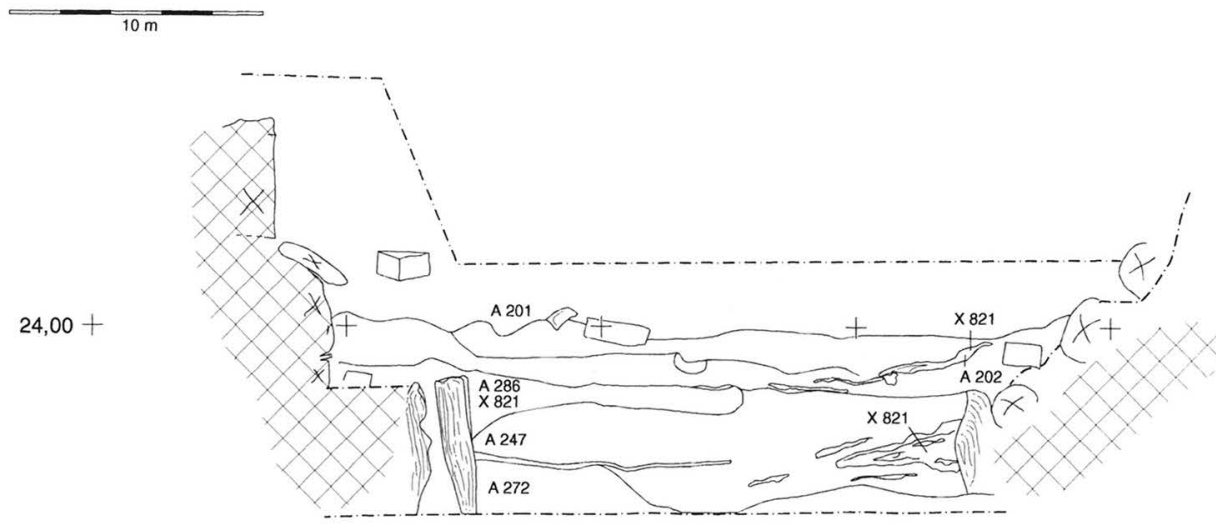

Fig. 11. Snit gennem kanalen midt i hospitalsbygningen. Lagene A247 og A272 består af udvasket sand aflejret, mens kanalen var i brug. Heri er opsamlet et meget varieret genstandsmateriale. Opmåling: Esben Klinker Hansen og Mikkel H. Thomsen. Streg: Sven Kaae.

Elevation of the canal underneath the hospital. The layers of A247 and A272 consist of washed sand deposited during the use of the canal and containing a varied find material. Measured by Esben Klinker Hansen and Mikkel T.Thomsen. Drawn by Sven Kaae.

at hindre bøgestammerne $\mathrm{i}$ at vælte ud i kanalen, var de holdt på plads med nedrammede egestolper. De kraftige stolper (ca. $25 \mathrm{~cm}$ i kvadrat) var anbragt lidt uregelmæssigt med afstande varierende fra ca. 1,2 til 2,0 m. Kanalens bredde mellem plankerne varierede lige omkring $2 \mathrm{~m}$.

Bag dette bolværk lå fundamentstenene oplagt uden mørtel, og det er derfor helt evident, at begge dele er etableret samtidigt. Dendrodateringer viser, at stolperne er fæeldet i 1494/95, hvilket må betyde, at udbyggelsen af fundamenterne til huset og opbygningen af kanalens bolværk blev foretaget i $1495 .{ }^{6}$

Fig. 12. Parti af kanalen set fra syd. Til venstre ses bolværket og fundamentet til den vestlige kælder fra 1495. Foto: HKK 1996.

Part of the canal seen from the South. The bulwark and the foundation of the western cellar from 1495 are seen to the right. Photo: the author, 1996.

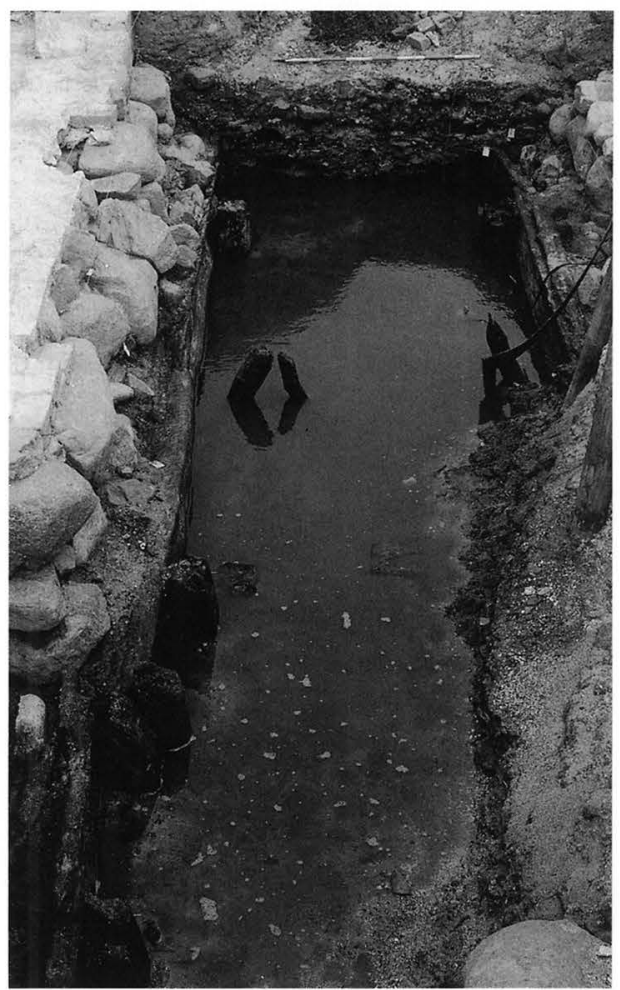




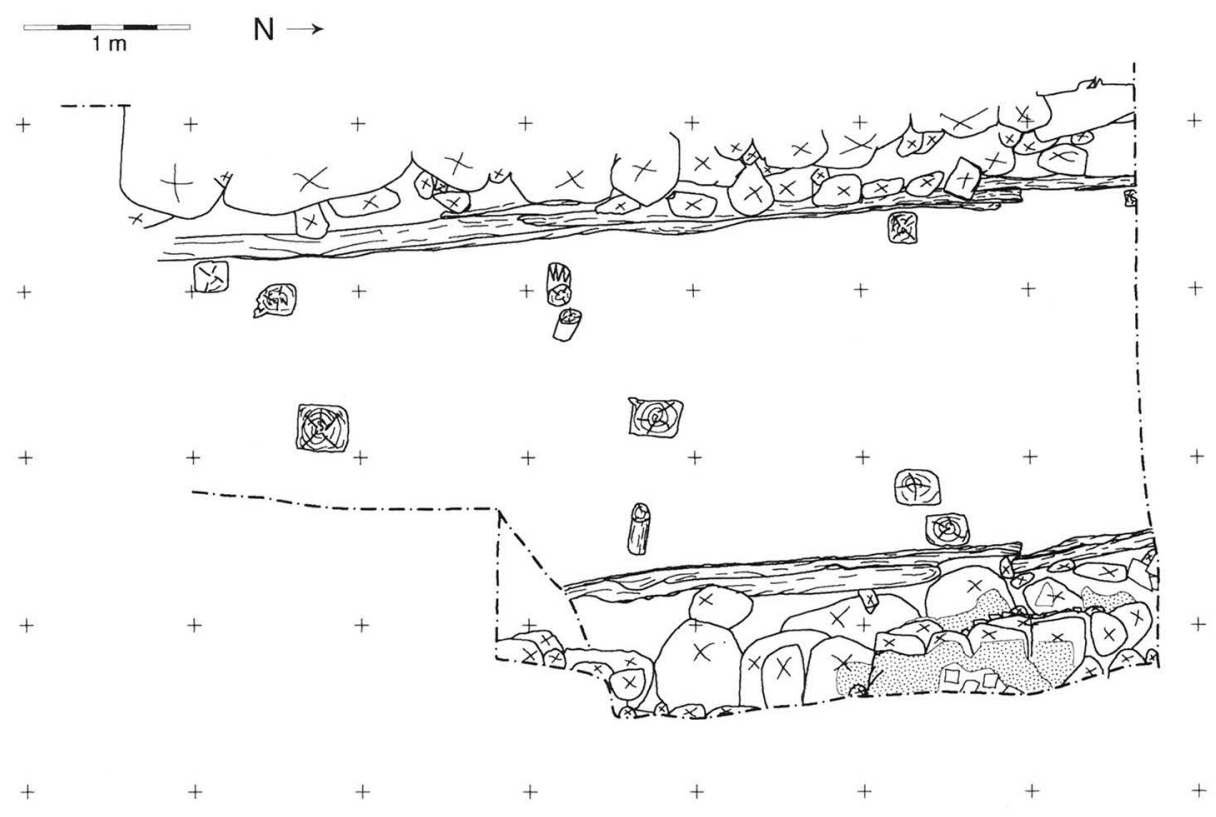

Fig. 13. Plan af kanalkonstruktion i den sydlige del af hospitalsbygningen. De kraftige stolper i midten tilhører kanalens ældste fase fra 1313. Opmåling: Esben Klinker Hansen og Mikkel H. Thomsen. Streg Sven Kaae.

Plan of the canal in the southern part of the hospital. The strong posts in the middle are from the older phase of the canal, from 1313. Measured by Esben Klinker Hansen og Mikkel H. Thomsen. Drawn by Sven Kaae.

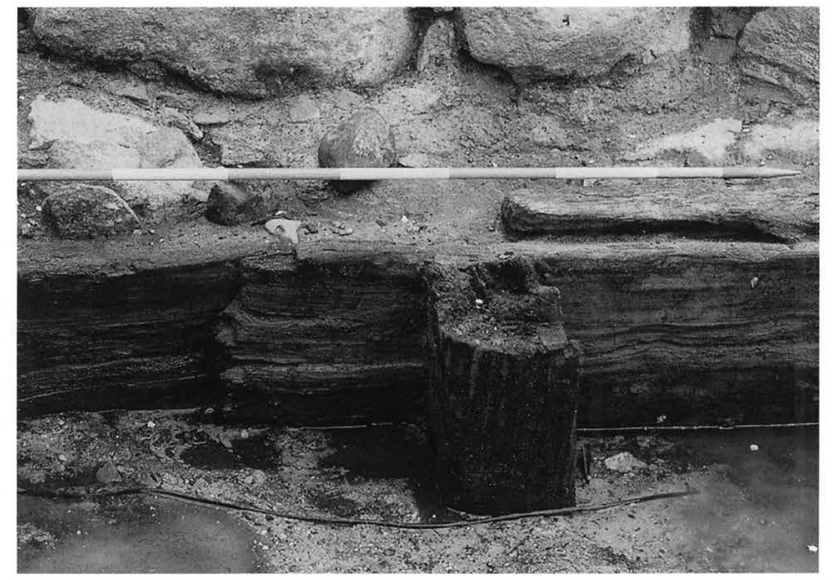

Fig. 14. Opbygningen af bolværket med kløvede bøgestammer og en tilhugget egestolpe, som holder det vandrette tømmer på plads. Foto: HKK 1996.

The structure of the bulwark with split beech trunks and a rough-hewn oak post, which holds the horizontal timber in its place. Photo: the author, 1996. 


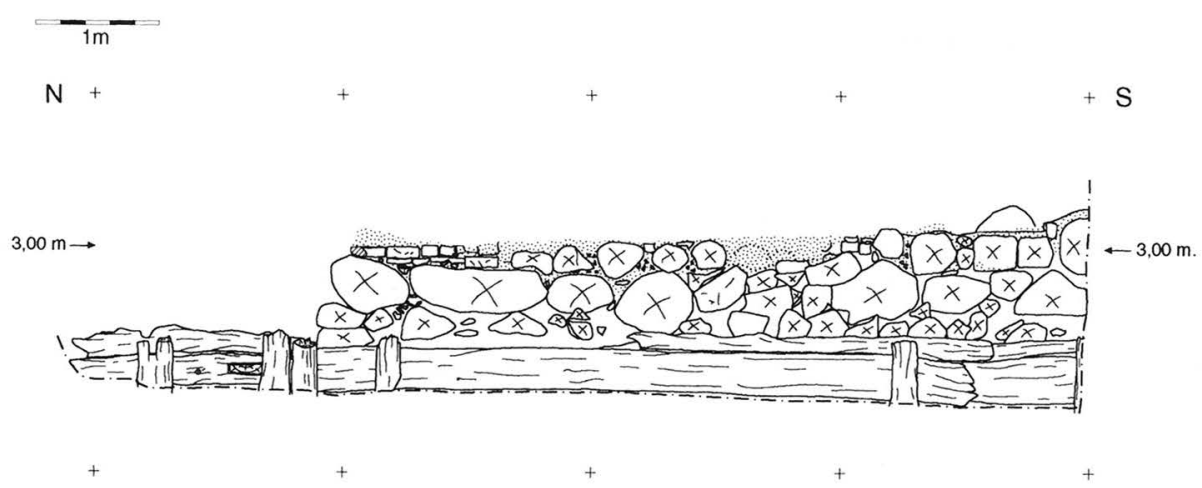

Fig. 15. Opstalt af bolværk og fundament på kanalens vestside. Opmåling: Susanne Gram. Streg: Sven Kaae.

Elevation of the bulwark and the foundation on the western side of the canal. Measured by Susanne Gram. Drawn by: Sven Kaae.

Den ældre kanal var knap så velbevaret, men formentlig konstrueret på samme måde. Også her bestod siderne af kraftige bøgeplanker holdt på plads af firkantede egestolper. Mod øst var der op til $2 \mathrm{~m}$ mellem stolperne. Den ældre kanal var muligvis en smule bredere end den yngste - ca. $2,25 \mathrm{~m}$. Ved ombygningen flyttedes kanalen en god meter mod øst, hvorfor de nedrammede stolper kom til at stå midt $\mathrm{i}$ det nye kanalforløb. Åbenbart var det umuligt at trække disse stolper op igen, hvorfor de alle var hugget over med en økse i højde med den nye kanalbund eller måske lidt højere (fig. 16). Den ældste kanal er dendrokronologisk dateret til $1313 .{ }^{6}$

Nord for den store bygning blev kanalen drejet mod øst med et skråt forløb gennem tilbyg-

Fig. 16. Kanalen under udgravning set fra nord. I forgrunden en overhugget stolpe fra det ældste kanalforløb. Foto: HKK 1996.

The canal during excavation seen from the North. The post in the foreground is from the older canal. Photo: the author, 1996.

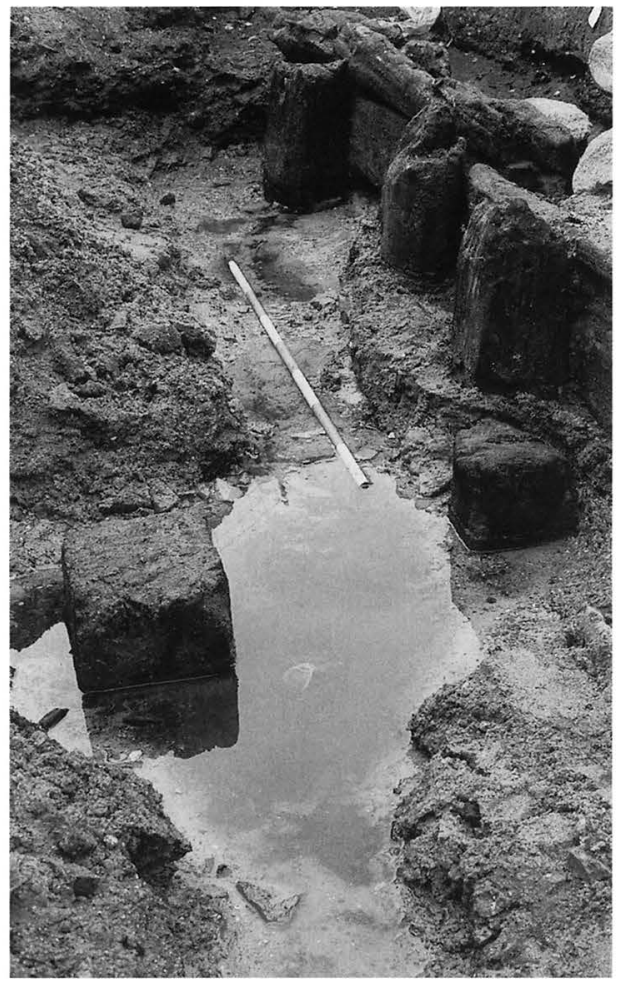




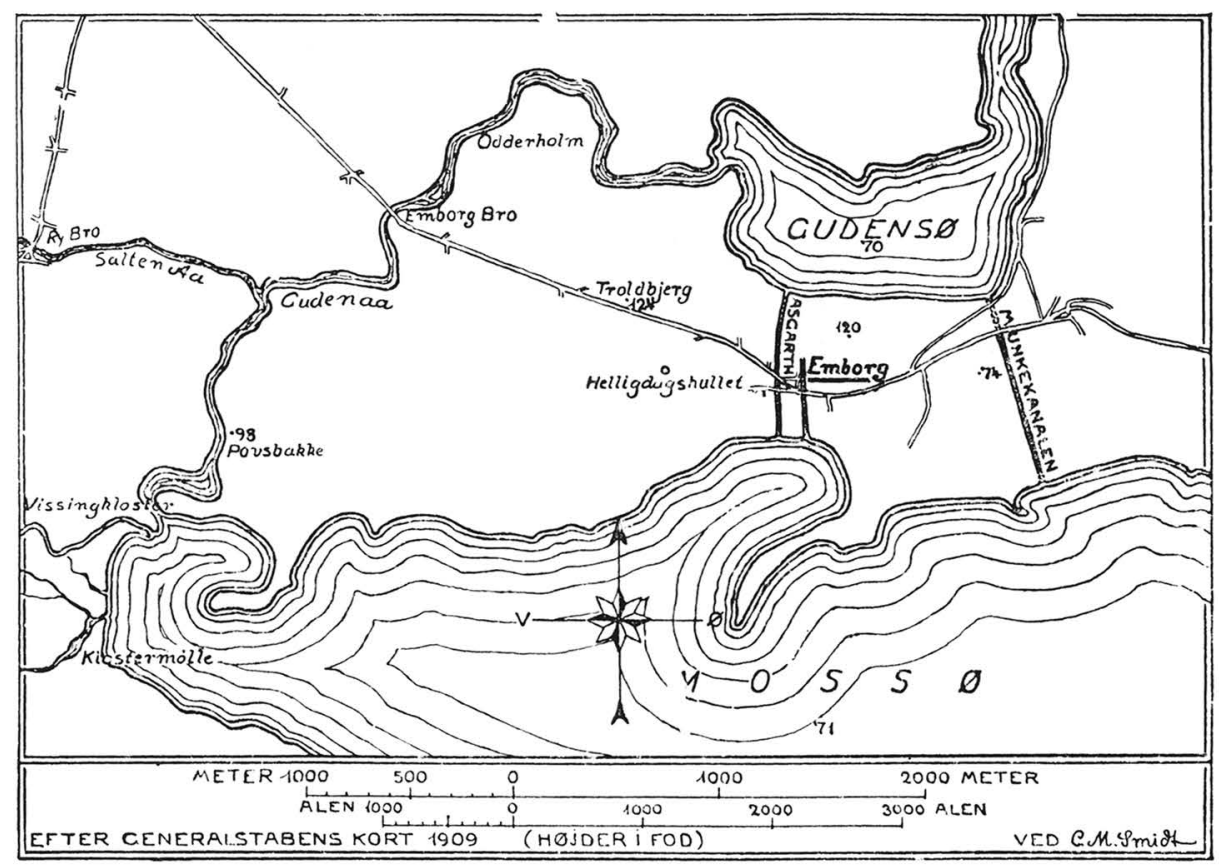

Fig.17. C. M. Smidts kort over Mossø, Gudensø og de forskellige vandløb, der forbinder søerne. Den vestlige klosterkanal opfattede Smidt som den ældste og er her kaldet Asgarth. (Efter Smidt og Isager 1968).

C. M.Smidt's map of the Mossø Lake and the Gudensø Lake and the different streams which connect them. Mr. Smidt considered the western Klosterkanal (Monastery Canal) as the older one. Here, he has called it Asgarth (From Smidt and Isager 1968).

ningen i en overhvælvet rende som tidligere nævnt. Kanalen blev endvidere påvist i 1978 længere mod nordøst (sydøst for kirkens kor). Her havde kanalen plankesatte sider og en bredde på $4 \mathrm{~m} .{ }^{7}$ Der synes ikke at være foretaget nogen udtømmende undersøgelse i det pågældende felt. Kanalens retning var sydvest-nordøst og den burde derfor i klostertiden være flydt sammen med den østre klosterkanal ud for kirkens kor.

\section{Kanalsystemet ved Øm Kloster}

Som nævnt ovenfor formodes hovedformålet med den nyfundne kanal at have været skyl af latriner og i det hele taget at tjene som spildevandsafledning. Antagelsen bygger mestendels på vores kendskab til forholdene andre steder.Ved velbelyste europæiske klosteranlæg ses hyppigt brug af kanaler til spildevandsafledning. Cistercienserne er ofte (skønt ikke de eneste) blevet fremhævet for deres effektive udnyttelse af kunstige vandløb. En berømt beskrivelse af klostret i Clairvaux fra ca. 1200 gennemgår omhyggeligt udnyttelsen af floden Aube til fiskedamme, kunstvanding, 
mølledrift, køkkenbrug, valkning, garvning samt spildevandsafledning. ${ }^{8}$ $\mathrm{Nu}$ var det de færreste steder, at kvaliteten i et større vandløb var egnet til drikkevand - så var brøndvand dog bedre. Det bedste var så afgjort kildevand tilført i trykledninger af blyrør, sammensatte teglrør eller udhulede træstammer. Nyere undersøgelser har vist, at sådanne trykledninger var ganske almindelige ved udenlandske klostre. ${ }^{9}$ Herhjemme kendes nogle teglrør fra Æ Æbelholt kloster. ${ }^{10}$ Muligvis fik man hjælp til arbejdet med denne ledning af den kyndige broder Stefan fra Esrum, som ifølge et brev var lånt ud til et arbejde med en vandledning. ${ }^{11}$ Så formentlig var systemet også kendt i Esrum.

\section{Broder Martin}

I tidens løb er der påvist spor efter forskellige kanaler omkring Øm Kloster. C. M. Smidt viste, at det centrale anlæg var omgivet af to kanaler (kaldet klosterkanalerne) og at der ca. $1 \mathrm{~km}$ længere mod øst var endnu en kanal mellem Mossø og Gudensø (fig. 17). Baggrunden for disse kanaler er klart fremstillet i klosterkrøniken:"De ... kom så til en grund som hedder Øm, omgivet til alle sider af vand og moser, og fandt der nærved skoven mellem to søer, Gudensø og Mossø, et sted, der var tæt overgroet med mange buske, og som tyktes dem at egne sig vel, hvis der blot ikke havde manglet vand til klostrets brug og nytte. En kunstfærdig munk, hr. Martin, målte da med et blylod vandstanden i begge søer og højden af det land, der skulle gennemgraves mellem dem, og derved fandt de, at vandstanden i den søndre sø var en alen højere end i den nørre. Deraf skønnede de, at de ville kunne fă vand til alt, hvorved de havde brug derfor, og at de aldrig for fremtiden ville mangle det." 12

\section{Den vestlige klosterkanal}

Den vestre kanal kan i dag tydeligt følges fra Mossø nordpå til klosterruinen. Ud for denne er terrænforholdene for tiden sådan, at kanalen nærmest ligger højere end klostertomten. Nord for ruinområdet kan kanalen følges som en sænkning, der krydser vejen til Gl. Rye.Videre nordpå mod Gudensø er kanalen over store træk ikke til at fă øje på; derimod er kanalens udløb i søen ganske tydeligt. C. M. Smidt har dog ganske tidligt hævdet, at kanalen forløb i en lige linje mellem Mossø og Gudensø, og ingen har siden rejst tvivl om dette forhold. ${ }^{13}$

Kanalen er undersøgt et par steder. Ud for kirkens vestgavl lavede C. M. Smidt i 1920 et snit på tværs af kanalen. ${ }^{14}$ Det kunne konstateres, at siderne var gravet med en vinkel på ca. $45^{\circ}$, og at de forneden var kantet med nedrammede pæle. Bag disse var der anbragt kampesten og teglbrokker for at beskytte mod erosion. Bredden af kanalen mellem stolperne var 
ca. $4 \mathrm{~m}$. Det var ikke muligt, at nå den oprindelige bund i kanalen; men den lå mindst $1 \mathrm{~m}$ under vandspejlet.

Lidt syd for klostertomten udgravede C. M. Smidt samme år et stemmeværk opbygget af solide egestolper, og han foreslog, det kunne være en møllesluse. ${ }^{15}$ En stolpe herfra blev trukket op og henlagt ved "Kirkehuset" i ruinparken. I vor tid er, hvad der formodes at være den pågældende stolpe dateret til kort efter $1237 .{ }^{16}$ Der er ikke i forbindelse med stemmeværket fundet spor efter en evt. mølle, men der er vist heller ikke gravet, hvor den i givet fald skulle have ligget. Det er dog også muligt, at stemmeværket er bygget, fordi det med flere kanaler i klosterområdet kunne være hensigtsmæssigt at regulere gennemstrømningen i de forskellige løb efter behov. I så fald kunne man forvente lignende stemmeværk i de øvrige kanaler.

Kanalen i vest løber meget tæt forbi den lange vestfløj i søndre klostergård, og det har da også været nødvendigt at placere stræbepiller på vestsiden. Lidt overraskende er der både op mod bygningens vestside og også ved sydvesthjørnet af det såkaldte sydhus anlagt en kampestensbygget brønd, som begge steder synes at være anbragt i kanten af kanalen. Det forekommer omsonst at bygge disse brønde så tæet på, da vandet heri måtte være af samme beskaffenhed som vandet $i$ kanalen, og så kunne man jo lige så let hente det direkte der. Der ville være mere mening i foretagendet, hvis brøndene i virkeligheden tilhørte en fase ældre end kanalen.

Ved udgravningen af kirkegården mod nord iagttog Anders Andersen, at over det middelalderlige vækstlag var der et lag af groft grus, som han forestillede sig måtte stamme fra den vestre kanal. ${ }^{17}$ Ved nogle begravelser var laget gravet igennem, mens andre var dækket heraf. Hvis iagttagelsen og tolkningen er korrekt, må kanalen være lavet, mens kirkegården var i funktion.

\section{Den østlige klosterkanal}

Den østre kanal blev påvist af C. M. Smidt i 1921 og kaldtes da den nyfundne kanal. ${ }^{18}$ Undersøgelsen blev foretaget syd for Emborg Bygade, hvilket vil sige ud for østfløjens sydgavl. Kanalforløbet kan godt fornemmes $i$ terrænet ned mod Mossø, når man ved, det er der. Derimod kan kanalen ikke erkendes omkring gården lige øst for klosterkirken; her skal den vestre længe ifølge Smidt ligge lige oven på kanalen. Længere mod nord fornemmes den igen og kan følges til et sumpområde med gamle tørvegrave, Klostermosen.

Fra C. M. Smidts undersøgelser ser det ud til, at kanalens sider i vandspejlsniveau var kantet af egeplanker, 10-15 cm tykke. Med mellemrum var plankerne fastholdt af firkantede egestolper (ca. 21-22 cm i kvadrat). 
Altså stort set samme konstruktion som i den nyfundne kanal fra 1990erne, dog var bredden nok lidt større - ca. $4 \mathrm{~m}$ mellem plankerne. Over plankekanterne skrånede siderne udad, så kanalens fulde bredde foroven var ca. $6 \mathrm{~m}$. Efter tegningen at dømme har man opgivet at fange kanalens bund - sandsynligvis på grund af problemer med indstrømmende vand. På en længere strækning var kanalen udfyldt med et meget solidt kampestensfundament. Fænomenet er opmålt, men ellers ikke kommenteret af C. M. Smidt. ${ }^{19}$ Her må have stået en grundmuret bygning, vi ellers ikke kender, og dens fundering må have ødelagt kanalen.

\section{Munkekanalen}

Den ca. 1 km lange Munkekanal er med undtagelse af et kort stykke nord for vejen mod Boes stadig markant synlig i landskabet mellem de to søer. Kanalen er udgravet med skrånende, ret stejle brinker. ${ }^{20} \mathrm{I}$ et snit ved vejen var bredden $8 \mathrm{~m}$ foroven og ca. $5,5 \mathrm{~m} 85 \mathrm{~cm}$ nede - bunden blev ikke nået. Der blev heller ikke som i de andre påvist nogen befæestelse af kanalens sider, og da undergrunden stort set har samme sandede karakter, burde det kunne forventes, hvilket tyder på, at udgravningen langt fra har nået bunden. Det opgravede materiale blev lagt på begge sider som lave volde. Munkekanalen er altså både bredere og længere end de to andre kanaler. Den er afgjort både en teknisk bedrift og en kæmpemæssig investering i arbejdskraft. Kanalens formål er ikke helt klarlagt; men det har utvivlsomt været noget, som de to klosterkanaler ikke tilfredsstillende har kunnet opfylde. Den større bredde har nok gjort den bedre egnet til pramfart end de to andre.

Hvilken kanal, der er ældst, altså lavet på baggrund af broder Martins nivellering i 1172, er derimod ikke så let at afgøre. C. M. Smidt opdagede først den vestre kanal, og den synes altid i hans opfattelse at være den oprindelige. ${ }^{21}$ Munkekanalen helt mod øst må nok også klart opfattes som et forholdsvis sent anlæg; det synes ikke rimeligt, at man skulle være startet med et kanalarbejde så langt fra klostret. Derimod er der intet, som umiddelbart fastslår, at den østre klosterkanal skulle være sekundær. Her ville det naturligvis være afgørende, om man fik fat på træværk fra kanalerne, som kunne dateres. Et kendskab til beliggenheden af 1100-tallets kloster ville muligvis også kunne have givet et fingerpeg om beliggenheden af broder Martins kanal.

\section{Vandstandsforhold $i$ klosterområdet}

I 1172 målte broder Martin forskellen på vandspejlet i Mossø og Gudensø til at være én alen. 


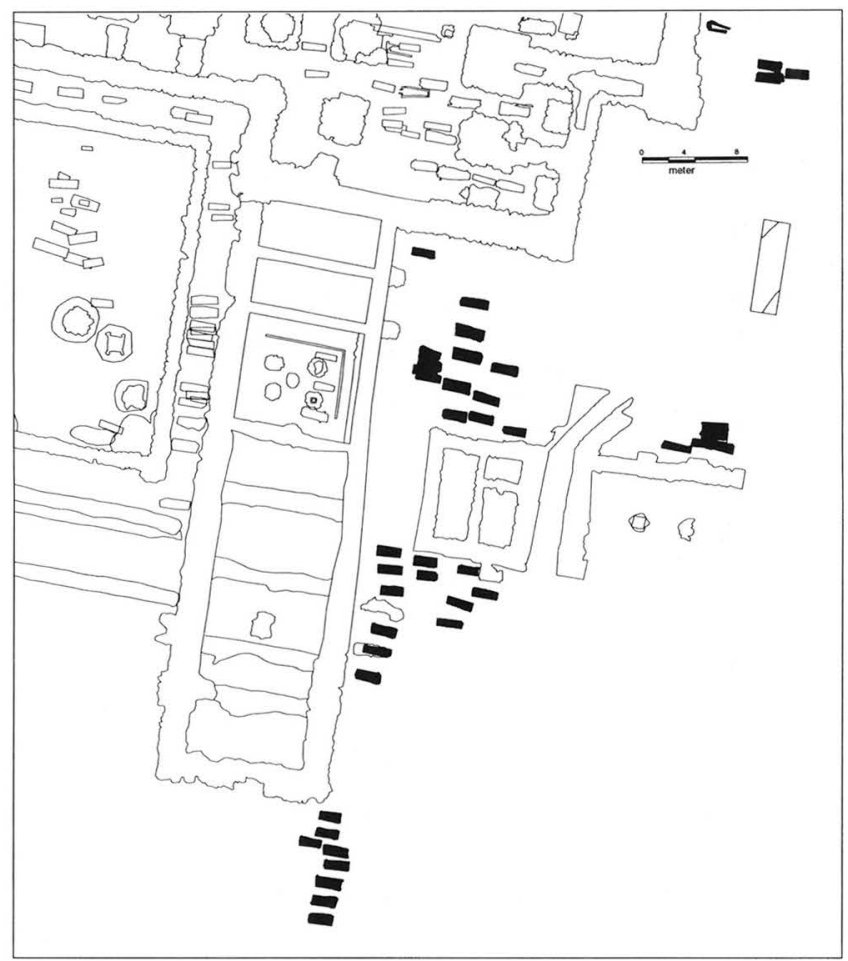

Fig. 18. Plan af gravene på Øm Klosters østre kirkegård. Det ses tydeligt, at gravene er lagt systematisk med kun enkelte forstyrrelser. Kirkegården blev dog voldsomt forstyrret ved anlæggelsen af kanalen i den xldste form i 1313

(Efter Lene Mollerup 1998).

Plan of the graves in the eastern churchyard of Øm Monastery. The graves are clearly laid out systematically with just a few overlaps. However, the churchyard was severely disturbed by the first canal construction in 1313. (From Lene Mollerup 1998).

Den 15. august 1921 nivelleredes forskellen af C. M. Smidt og landinspektør Eriksen, og den beregnedes til 6,0 decimaltommer $=$ ca. $15 \mathrm{~cm}^{22}$ C. M. Smidt nivellerede vandspejlet i de to søer igen den 21. august 1928 og nåede da frem til, at forskellen var på $18 \mathrm{~cm} .^{23}$

Forskellen er altså i dag noget mindre end broder Martins ene alen. Spørgsmålet er da også, om man i det hele taget i middelalderen ville have kunnet registrere en forskel på blot $15 \mathrm{~cm}$. Det er måske også et spørgsmål, om et så beskedent fald har været tilstrækkeligt til de forskellige funktioner, som kanalerne skulle tjene. På den anden side blev kanalerne gravet, og hvis de ikke fungerede, havde man næppe lavet dem alle. Så mon ikke forskellen var større i middelalderen.

I dag er der en ganske betydelig opstemning ved Ry Mølle, som utvivlsomt har indvirkning på vandstanden opstrøms, bl.a. i Gudensø.

\section{Kirkegården}

I forbindelse med udgravningen af hospitalsbygningen og kanalen påvistes en række middelalderlige grave. Kun få af disse blev tømt, så der blev mulighed for en undersøgelse af skelettet. I de fleste tilfælde er der blot registreret et fyldskifte $i$ undergrunden af form som en grav. Der kan der- 


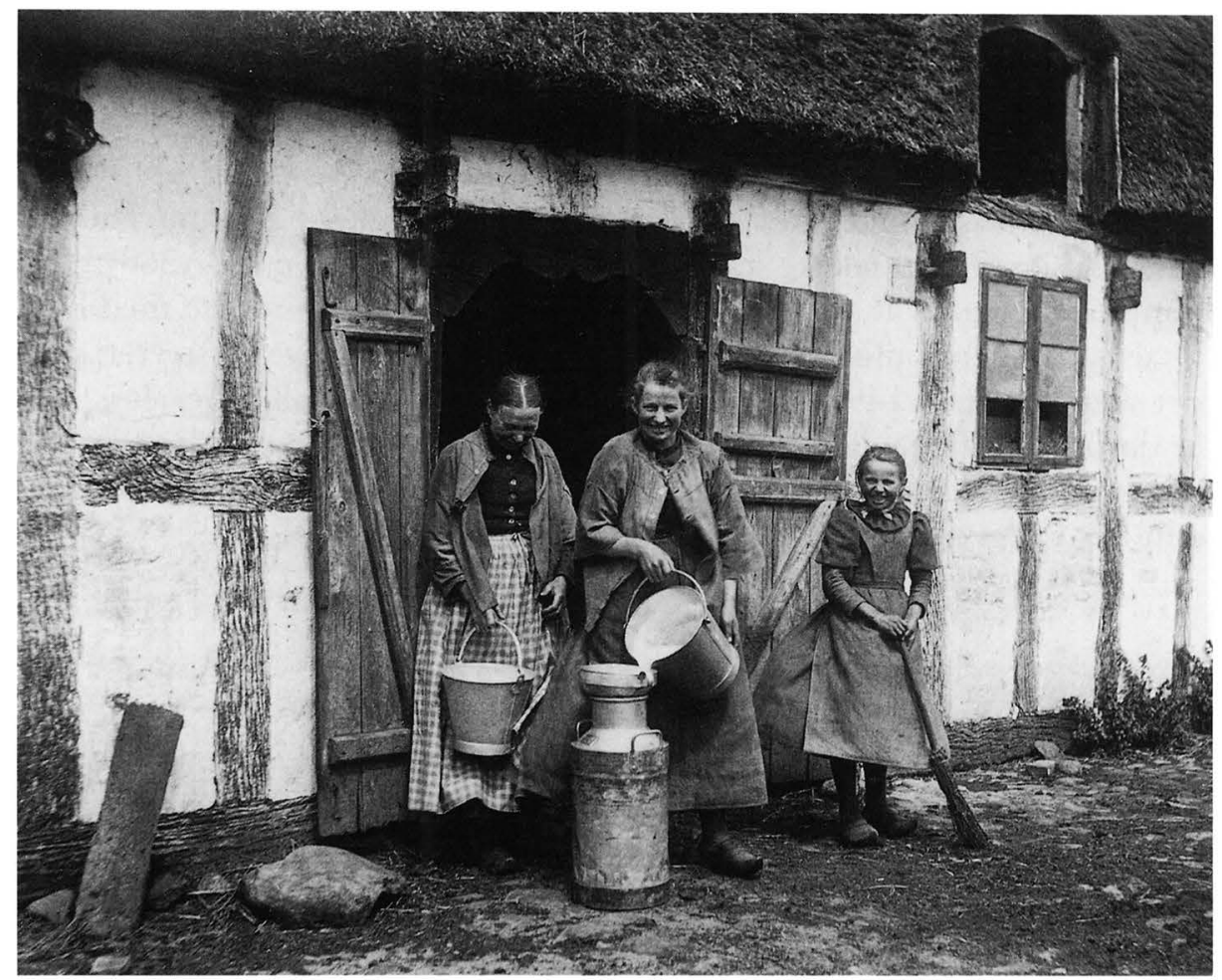

Fig. 19. Malkescene i Emborg i 1896. Døroverliggeren med en kølbuevariant udskåret i meget svært egetømmer er næppe lavet til kostalden i en almindelig bondegård. Der er ingen tvivl om, at dette tømmerstykke og sikkert meget andet tømmer i bygningen stammer fra klostrets ladegård. Foto: Ivar Hertzsprung, Nationalmuseet.

Milkmaids in Emborg, 1896. The lintel is carved from solid oak and was probably not made for the cowshed of a normal farm. No doubt the lintel and probably a lot of the other timber in the building stem from the farmhouses belonging to the monastery. Photo: Ivar Hertzsprung, the National Museum.

for $i$ virkeligheden være en grav mere eller mindre, men det har dog ingen betydning i en større sammenhæng. I øvrigt er der også tidligere (C. M. Smidt i 1921 og Jens Ingvordsen i 1985) påvist grave i området øst for østfløjen. ${ }^{24}$

Sammentegnet viser gravene en for middelalderen bemærkelsesværdig systematisk kirkegård (fig. 18). ${ }^{25}$ Gravene ligger pænt i rækker følgende østfløjen. Der synes at kunne skelnes 6-7 rækker, hvor dog de østligste rækker kun er belagt med ganske få iagttagelser. Inden for rækkerne er gravene placeret ret regelmæssigt, og der er kun ganske få tilfælde, hvor gravene skærer hinanden. De undersøgte skeletter stammer alle fra mænd, og alt tyder også på, at der er tale om munkenes kirkegård. Konventets størrelse er ikke kendt, men et kvalificeret gæt kunne være 30 munke, hvilket ikke bliver til mange begravelser årligt. Brugen af dette 
kirkegårdsafsnit har derfor været ret langvarig, og det betyder, at de enkelte gravsteder har været markeret i en lang periode, således at forstyrrelser er undgået ved nye begravelser.

Gravene er orienteret i forhold til østfløjen, som var under opførelse i 1246, da abbed Mikkel blev gravlagt i den endnu ufærdige kapitelsal.Ved anlæggelsen af den ældste kanal i 1313 blev én af gravene (A268) gennemskåret, således at skelettets underben mangler. I forbindelse med hospitalsbygningens opførelse blev også en række andre grave forstyrret; men det skete jo først i 1495. Indgrebet i gravfreden ved kanalbyggeriet i 1313 er derimod påfaldende $\mathrm{i}$ forhold til den pietet, man ellers synes at kunne spore i den velordnede kirkegård. Man må derfor gå ud fra, at kirkegården har været nedlagt et godt stykke tidligere.

\section{Kirkekvadre}

I hospitalsbygningens fundamenter indgik en del genanvendte granitkvadre. Der er tidligere nævnt to sokkelkvadre ved den specielle åbning $i$ vestendens nordmur og kvaderen med smig ved afløbet ud til kanalen. Denne kvader stammer ret sikkert fra et smiget, romansk vindue. Desuden blev der fundet flere almindelige, ukarakteristiske kvadre forskellige steder i bygningen. Man har altså i forbindelse med byggeriet haft adgang til et beskedent antal granitkvadre. Der er næppe tale om en hel nedreven kirke, men snarere lidt overskudsmateriale fra en ombygning. Spørgsmålet er så, om kvadrene stammer fra den kendte klosterkirke indviet i 1257 eller fra en anden kirke. Teglstenskirken fra 1200-tallet havde utvivlsomt en granitsokkel; men efter mængden af bevarede sokkelsten i ruinparken at dømme, var der tale om en sokkel med hulkehlet skråkant - helt anderledes end de to genbrugte sten med rundstav. Den omtalte klosterkirke har næppe heller haft kvadersatte vinduer. Granitkvadrene kan så stamme fra en fremmed kirke eller fra den klosterkirke, munkene benyttede før 1257. Da de kom til Øm allerede i 1172, har de altså i 85 år haft en anden kirkebygning. I så lang tid har man ikke kunnet nøjes med en midlertidig trækirke, så der er en stor sandsynlighed for, at munkene i slutningen af 1100-tallet lod opføre en mindre klosterkirke i granitkvadre. Her blev biskop Svend gravlagt i 1191. Omkring 1490 blev der lagt en stor, ny gravsten over Svends grav, så med mindre graven var flyttet, har den gamle kirke stadig været bevaret i klostret. Hører den nye gravsten mon sammen med en generel modernisering af denne kirke, hvorved nogle kvadre blev overflødige? 


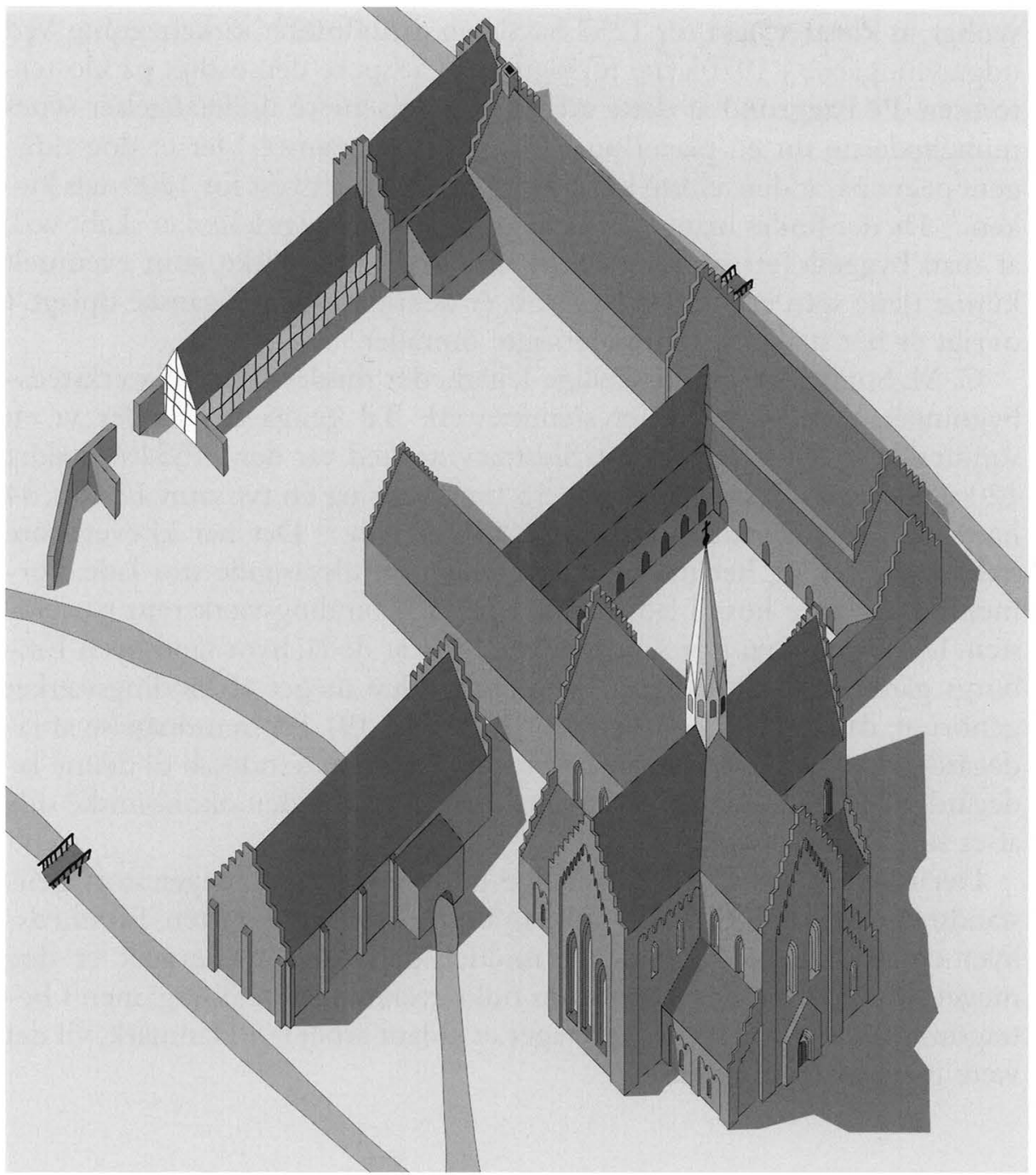

Fig. 20. Rekonstruktion af klosteranlægget i Øm o. 1500. Hospitalsbygningen i forgrunden gennemstrømmes af en kanal. Rekonstruktion: HKK. Streg: Tegnestuen, Moesgård.

Reconstruction of the monastery showing the hospital building with its extension on the eastern side of the east wing.

\section{Afslutning}

Udgravningen viste, at selv her i Danmarks bedst undersøgte klostertomt er det stadig muligt at finde betydelige rester af et meget stort og kompliceret bygningskompleks.

Hermed er mulighederne og behovet for arkæologiske undersøgelser i tomten langt fra udtømt - tværtimod. Som nævnt ovenfor er det sand- 
synligt, at klostret også før 1257 havde en grundmuret kirkebygning. Ved udgravningerne i 1970'erne forsøgte man at spore den østligt på klostertomten. På baggrund af dette arbejde og de seneste undersøgelser synes mulighederne for en placering her nok ret begrænset. Der er dog tidligere peget på, at den ældste kirke kunne have ligget vest for 1200-tals kirken. ${ }^{26} \mathrm{Da}$ der findes mange eksempler på, at kirkeudvidelsen er skabt ved, at man byggede et nyt korparti øst for den gamle kirke, som eventuelt kunne tjene som et midlertidigt skib, er denne mulighed ganske oplagt. I øvrigt er her stadig store uundersøgte områder.

C. M. Smidt har ved forskellige lejligheder fundet rester af værkstedsbygninger, en teglovn og et stemmeværk. Til gengæld mangler vi en vandmølle og en stor ladegård. Sidstnævnte sted var der i 1554 opstaldet 120 staldøksne, 27 køer, 16 kvier, 15 trækokser og én tyr samt 120 făr, 34 heste og føl af forskellig art plus 100 løse svin. ${ }^{27}$ Det har krævet store staldbygninger, og her må også have ligget en tilsvarende stor lade. Formentlig var disse huse i ladegården opført af bindingsværk rejst på syldsten. Der er også en stor sandsynlighed for, at de lå, hvor landsbyen Emborgs gårde kom til at ligge. Formentlig blev meget af bindingsværket genbrugt, da landsbyen oprettedes i 1572 (fig. 19). En fremdragelse af ladegården kan derfor blive ganske vanskelig, men et kendskab til denne ladegård ville på afgørende vis forøge vores viden om den økonomiske side af et landklosters virke.

Derimod er der fra de forskellige undersøgelser et meget stort genstandsmateriale til rådighed, som kan belyse bygningskunsten, fromhedslivet og dagligdagen $i$ et dansk middelalderkloster. Materialet er dog meget omfangsrigt og vil fordre en tidkrævende bearbejdning; men i betragtning af, at der aldrig er foretaget et sådant arbejde i Danmark, vil det være meget kærkomment.

\section{NOTER}

1) Se sammentegningen ved Kjeld de Fine Licht, Danmarks Kirker, Århus Amt, fig. 5, s. 3782. Bygningen er kort nævnt i Olsen 1979, s. 21. Bygningskomplekset og udgravningshistorien er behandlet i Gram 1978.

2) Undersøgelsen blev foretaget i samarbejde med Skanderborg Museum og har jour.nr. SBM 484.Ved udgravningen deltog stud.mag.'erne: Marin Borring Olesen, Jørn B. Lund, Lone Vel Jeppe, Jan Simmen, Thomas Philipsen, Lars Agersnap Larsen. Mie Mørck, Camilla Poulsen, Martin Rasmussen, Anne Louise Wraae, Anne Katrine Thaastrup-Leth, Thomas Bertelsen, Annette Madsen, Jesper Bade og Bente Hansen i 1994, Sidsel Tefre, John R. Mirland, Tina G. Nielsen, Mette Busch, Søren Sørensen, Sverre Carlsson, Heidi Maria Møller Nielsen, Rikke Isler, Charlotte Styrup Jensen, Mette Højmark, Lars Bentsen, Pelle Klit Christensen, Pernille Madsen, Anders von Buchwald, Martin Favrbo, Kirstine Korshøj Jørgensen og Thomas Hunnicke i 1995, Brigitte H. Christiansen, Lone Højrup, Marie Krogh-Nielsen, Annette Rasmussen, Mikkel H. Thomsen, Helgi Michelsen, Preben Grube, Lars Rune Christensen, Thomas N. Andersen, Janne F. Sørensen, Esben Klinker Hansen, Martin Kappel Andersen, Alice Mad- 
sen, Morten Søvsø, Mette Brun Knudsen, Jane Jark Jensen og Karen Bork-Pedersen i 1996. Stud.mag. Susanne Nissen Gram var assistent alle år. Udgravningerne blev ledet af forf.

3) Isager 1942.

4) Mollerup 1998, s. 133.

5) Lind og Garner 1993. Analyser fra lag afsat i kanalen under den formodede hospitalsbygning har i øvrigt påvist frø fra en lang række lægeplanter; Robinson \& al. in print.

6) Eriksen 1997, s. 2.

7) Øm Kloster-projektet nr. 11, s. 5, Gram 1998 s. 83.

8) Beskrivelsen af Clairvaux af en anonym forfatter er oversat til dansk i Frandsen m.fl. 1977, s. 72-77.

9) Kosch 1991, s. 99-108.

10) Hertz 1962, s. 3-4.

11) På latin kaldet aquæductus. Diplomatarium Danicum 1, III, 2. del Abbed Vilhelms Breve II 35.

12) Øm Klosters Krønike, s. 17.

13) Smidt 1939, s. 104; Smidt 1942, s. 10-11 \& 24.

14) Gram 1998, s. 24-25 \& 175; Smidts notesbog LXXV (1920 ff.), s. 21-22..

15) Smidt 1939, s. 104; Smidt 1942, s. 24-25.

16) Gram 1928, s. 149, note 174.

17) Mollerup 1998, s. 95. Nogle trækistegrave var anlagt før det påfyldte "søgrus", mens to murede grave var yngre end dette lag.

18) Gram 1998, s. 36 + bilag XIII; Smidt 1939, s. $11 \& 24$.

19) Gram 1998, s. 36.

20) Beretning i Skanderborg Museum, jour.nr. SBM 64/87.

21) Eksempelvis i Smidt 1968, s. 12. Smidts argumentation er diskuteret i Ingvordsen 1990/91, s. 55-56.

22) Smidts notesbog LXXV, s. 12-13.

23) Smidts notesbog LXXV, s. 125-127.

24) Mollerup 1998, s. 25 \& 33.

25) Mollerup 1998, s. 40.

26) Madsen 1977, s. 154.

27) Suhm 1794, s. 308-309.

\section{LITTERATUR}

Danmarks Kirker, Århus Amt. København 1968-.

Diplomatarium Danicum, udg. af Det danske Sprog- og Litteraturselskab (oversættelser i Danmarks Riges Breve). København 1938-.

Eriksen, Orla Hylleberg 1997: Dendrokronologisk undersøgelse af tree fra kanalanlag ved Øm Kloster, Arhus amt .NNU rapport nr. 8. København.

Frandsen, Søren, Jens Anker Jørgensen og Chr. Gorm Tortzen (red.) 1997: Bogen om Esrum Kloster. Frederiksborg Amt.

Gram, Susanne Nissen 1998: Øm Kloster, Bygningskompleksets udformning og udbygningsforløb. Højbjerg.

Hertz, Johannes 1962: Moderne bekvemmeligheder. Skalk 1962:3, s. 3-6.

Ingvordsen, Jens 1990/91: Asgarth og broder Martins kanal, bidrag til Øm klosters topografi. A hus Stifts Arbeger 1990/91, s. 45-79.

Isager, Kr. 1942: Skeletfundene ved Øm Kloster. København .

Kosch, Clemens 1991: Wasserbaueinrichtungen in hochmittelalterlichen Konventanlagen Mitteleuropas, Die Wasserversorgung im Mittelalter. Klaus Grewe (ed.): Geschichte der Wasserversorgung bd. 4. Mainz.

Lind, J. og H. N. Garner 1993: Klosterhaven i Øm. Øm. 
Madsen, Per Kristian 1977: Bispegrave på Øm kloster. Hikuin 3, 1977, s. 137-156.

Olsen, Olaf 1997: Krønike og udgravning, Øm kloster i historisk og arkæologisk belysning. Convivium 1997, s. 2-22 (udgivet som særtryk af Historisk Samfund for Århus Stift).

Robinson, David Earle, Jan Andreas Harild \& Ida Boldsen (in print): Danish medieval monastery Gardens - the archaeobotanical evidence from St. Peter's Monastery, Odense and Øm Monastery near Ry. Journal of danish Archaeology .

Smidt, C. M. 1939: Øm Kloster, Klosterkrøniken og Udgravningen. Århus Stifts Aarboger XXII, 1939 , s. $101-116$.

Smidt, C. M. 1942: Øm Kloster. Arrhus Stifts Aarbøger XXXV, 1942, s. 1-45.

Smidt, C. M. og Kr. Isager 1968: Øm Kloster, Cara Insula. Udg. af Historisk Samfund for Århus Stift, 3. forøgede udgave, 5. oplag, Århus.

Suhm, P. F. 1794: Nye Samlinger til den Danske Historie bd. III (Øm Klosters Inventarium 1554, s. 302-325), Kjøbenhavn.

Øm Klosters Krønike, oversat af Jørgen Olrik. Udg. af Historisk Samfund for Århus Stift i flere oplag, her 1964.

\section{UTRYKT MATERIALE}

Mollerup, Lene 1998: Begravelserne ved Øm Kloster, En analyse af gravenes udsagn-Datering, udformning, personsammensatning. Utrykt specialeafhandling ved Middelalderarkæologi, Aarhus Universitet.

C. M. Smidts notesbøger, Nationalmuseet. Øm Kloster-projektet, NYT fra de arkcoologiske udgravninger, nr. 1-11, 1975-78. Stencilerede nyhedsbreve udgivet af Øm Kloster-projektet, Moesgård.

\section{The hospital of the Øm Monastery The archaeological investigation of a large, late medieval building}

During the years of 1994-96, the Department of Medieval Archaeology at Aarhus University undertook the excavation of a large building built across a canal east of the eastern wing of the monastery (figs. 1-2).

The house was $10.8 \mathrm{~m}$ wide and originally had a length of at least 29.5 metres. However, the eastern gable was not found, as it lies underneath the present village street. Only parts of the cellar are preserved (figs. 5-8). At this level the canal divided the house into two parts, whereas the upper floors must have been adjoining. In the West, partition walls divided the cellar into three rooms, whereas the eastern part constituted one large room, which was covered by vaults resting on strong, square pillars along the central axis (figs. 3-4). This part of the building also had buttresses, which suggest that the upper floor was also vaulted. This was probably a tall and light room with a double nave, the vaults of which rested on slender granite columns. Fragments of such columns with a diameter of 20-22 centimetres were found during the excavation. Presumably the building was a hospital accommodating the sick in the vaulted hall and with lavatories above the canal.

At some time a small extension $(5.1 \times 6.4$ metres) was built onto the northern side of 
the building (figs. 2, 3, and 9). This small building was also situated over the canal, which was at this place constructed as a brick-built drain with a barrel vault (fig. 10). No doubt the building was made in order to transfer the lavatory function from the house to this extension.

The canal under the house was edged by a bulwark made of split beech logs, held in place by oak posts driven into the ground (figs. 14-15). The investigation established two canals (fig. 13) the older of which was constructed in 1313 (fig. 16) whereas the younger one had been built at the same time as the house, in 1495 (fig. 12). Deposited layers in the bottom of the canal were rich in finds and remnants of plants (fig. 11). The beginning of the canal farther to the South was not established, but an investigation in 1978 shows that it turned northeast outside the church chancel. It is therefore thought to have joined the eastern monastery canal.

The canal was thus part of a larger system. The two Klosterkanaler (Monastery Canals) which surrounded the central monastery buildings have been known for a long time, as well as the Munkekanalen (Monks' Canal) around 1 kilometre farther east (fig. 17). The monks made use of the fact that the water level of the Gudensø Lake is a little lower than that of the Mossø Lake. According to the $Ø \mathrm{~m}$ Monastery Chronicle, this difference was established by the skilled Brother Martin in 1172 and was the reason why the monks settled here. Martin measured the difference to be two feet. In modern times, the damming at Ry Mill probably influenced the water level of the Gudensø Lake by reducing the level difference (which the archaeologist C. M. Smidt measured to be 15-18 centimetres).

The new canal clearly functioned as a sewer, which may partly be true also for the eastern and western Klosterkanal. Apart from this, the canals might have fed water mills and other installations.

The excavation established that the area east of the eastern wing functioned as a churchyard before the erection of the house and the building of the first canal in 1313 (fig. 18). The graves were oriented according to the east wing (which was under construction in 1246) and were systematically arranged in such a way that they only rarely overlapped. Thus, the graves must somehow have been individually marked to avoid disturbance of them. This part of the churchyard was probably used only for men and thus should be considered used exclusively for interring monks. North of the church, a large churchyard for the lay was previously excavated. The convent presumably had a limited size and therefore only a few funerals every year.

The excavation showed that even in the best-investigated monastery site in Denmark, it is still possible to find considerable remnants from a large and complicated building complex. Yet, much is still missing, as written sources tell of large stables and the complex must have incorporated a similarly large barn. These farmhouses were probably half-timbered and most likely were situated where the village of Emborg emerged later. Much of the half-timbering was probably reused when this village was established in 1572 (fig. 19).

Hans Krongaard Kristensen Afdeling for Middelalderarkæologi Aarhus University Moesgård

Translated by Annette Lerche Trolle 
